\title{
Burial Ritual, Agriculture, and Craft Production among Bronze Age Pastoralists at Tasbas (Kazakhstan)
}

\author{
Paula N. Doumani ${ }^{\text {a }}$ \\ (Corresponding Author) \\ pauladoumani@wustl.edu \\ (+1) 314-458-5433 \\ Michael D. Frachetti ${ }^{\text {a }}$ \\ frachetti@wustl.edu \\ Rebecca Beardmore ${ }^{\mathrm{b}}$ \\ rebecca.beardmore.09@,ucl.ac.uk \\ Tekla M. Schmaus ${ }^{c}$ \\ tschmaus@indiana.edu \\ Robert N. Spengler III ${ }^{\mathrm{a}}$ \\ rnspeng1@,wustl.edu \\ Alexei N. Mar'yashev d \\ gumir2@gmail.com
}

\footnotetext{
${ }^{a}$ Washington University in St. Louis, Anthropology Department, CB 1114, One Brookings Dr., St. Louis, M.O. 63130, +1(314) 458-5433.

${ }^{\mathrm{b}}$ University College London, Institute of Archaeology, 31-34 Gordon Square, London WC1H 0PY, United Kingdom, +44 (0) 2076797495.

${ }^{\mathrm{c}}$ Indiana University, Department of Anthropology, Student Building 130, 701 E. Kirkwood Avenue, Bloomington, IN 47405-7100, +1 (812) 855-1041.

d Institute of Archaeology, 44y. Dostyk, Almaty, 050010, Republic of Kazakhstan
} 


\subsection{Introduction}

Bronze Age Eurasian pastoral societies shaped wide-scale circulation of animal husbandry practices, bronze metallurgy, horse riding, and chariot technology across Eurasia (Frachetti 2012, Hanks and Linduff 2009, Mei 2009). Pastoral migration unequivocally provided a key vector for the spread of these phenomena - although diverse interpretations surround their nature (e.g., Anthony 2013, Frachetti 2011). Conventional images of Bronze Age Eurasian pastoralists rely on proposed long-distance migrations across the Eurasian steppe terrain. This traditional paradigm is grounded in a long history of culture-historical studies of regional pottery assemblages (and material classes such as metal objects) (Anthony 2008, Kuz'mina 2007) attempting to identify the time and place of regional cultural formations (Koryakova and Epimakhov 2007).

More recent archaeological studies of settlement complexes in central Eurasia present a different view of pastoralist mobility, technological innovation, and subsistence (Frachetti 2008, Hanks and Doonan 2009, Rouse and Cerasetti 2013). For example, growing archaeological evidence from mountain, steppe, and desert contexts illustrate diverse forms of pastoralism that incorporated varied forms of mobility and diets supplemented with farming, fishing, foraging, and/or hunting (Bendrey 2011, Murphy et al. 2013, Spengler et al. 2013a, Miller et al. 2014). The diversity of 'pastoral' economies evident across Eurasia not only highlights the growing need for robust and detailed descriptions of how Bronze Age groups made a living, but also the need to understand changes in technology and craft production, their manner of integration into local domestic and ritual life, and their transmission at wider scales.

This article provides a case example for the relationship among seasonal activities of craft production and subsistence, mobility, and site use among Bronze Age food producers of the Dzhungar Mountains, Semirech'ye, in Kazakhstan (Figure 1). Standard archaeological interpretations 
of its Bronze Age society and economy describe small pastoral groups who practiced short-distance vertical transhumance between winter and summer camps - a model both developed from archaeological data and ethnographic analogies to central Eurasian pastoralists (Frachetti 2008). The greatest (permanent) architectural investment and material remains are found at elevations below $1000 \mathrm{~m}$. asl whereas sites at higher elevations may have contained more temporary shelters making them difficult for archaeologists to locate. Settlement archaeology along its lower mountain foothills $(<1000 \mathrm{~m}$. asl) has also yielded more detailed reconstructions of presumed winter activity where animal husbandry was the dominant economic strategy, with little to no investment in crop agriculture (e.g., Frachetti and Mar'yashev 2007, Frachetti et al. 2010a, Rogozhinsky 2011). Less archaeological excavation has focused on higher elevation campsites thus, to date, limited comparative data exists for relating summer and winter practices of Bronze Age groups, or at the very least the different lifestyles practiced across the piedmont zone (but see Panyushkina et al. 2010).

Here we present archaeological data from Tasbas, a recently excavated highland settlement (Figure 1) located at $1500 \mathrm{~m}$ asl, in the Bayan-Zhurek Valley of Semirech'ye. The valley is flanked to its east by the forested and snow capped Dzhungar Alatau and to its west by a chain of basalt outcrops and granite formations that shelter numerous flat ravine terraces along their southern edge. Permanent rivers, seasonal streams, and river tributaries crisscross a mosaic of riparian areas, grassdominant fields, mixed forbs/grass fields, and low-growing shrubby forests around the site (Figure 2). The site of Tasbas is tucked against large granite boulders along southward slopes that face the towering Dzhungar Alatau. Numerous other small campsites have been identified around Tasbas, yet only a few of them documented (Baipakov and Mar'yashev 2008).

Tasbas extends over three natural terraces $(70 \times 20 \mathrm{~m})$ that wrap along a tributary river. Historic period burials rest on the upper terrace; a multi-phase campsite occupies the middle terrace 
(10 x $20 \mathrm{~m})$; and Late Bronze Age burials span the lower terrace. Pilot excavations were carried out on the middle terrace at Tasbas in 2001 by archaeologists from the Institute of Archeology in Almaty, Kazakhstan (Mar'yashev 2002), whom identified Bronze Age and Kazakh Period occupation phases. Revisiting these results ten years later, we identified compelling comparisons with ceramics and construction features from Begash, one of the few pastoralist settlements dating to the $3^{\text {rd }}$ millennium B.C. in Semirech'ye (Frachetti and Mar'yashev 2007:Fig. 6). Thus, in 2011, we initiated new excavations at Tasbas to date the site using absolute methods and recover more comprehensive data for economic reconstruction (Figure 3). Our excavations at Tasbas yielded evidence for early ritual activity, multi-season residence, and a mixed economy -- all of which underscore the point that within the broad dynamics of mountain pastoralism there is local variability. Tasbas illustrates local variation within a broader system of Eurasian pastoralism identified elsewhere in the region (Frachetti et al. 2010a).

\subsection{Material and Methods}

The 2011 excavations at Tasbas uncovered a multi-phase campsite with successive reoccupation events across a 5,000 year period. Archaeologically, the site and its associated material culture reveal four chronological phases (Figure 4a, 4b): a ritual and domestic structure; a domestic architectural construction; an outdoor activity area; and a foundationless encampment. Eleven AMS dates provide the Bronze Age occupation history (Table 1). A spectrum of high-resolution material analyses was also employed to reconstruct the hitherto unrecorded Bronze Age economy and craft production practices at higher mountain elevations.

Pottery samples were examined with formal and archaeometric techniques ${ }^{1}$. Formal identification of manufacture techniques were based on work by Rye (1981). Digital radiographs were produced at Argonne National Laboratory (ANL) using protocols developed by Greene and

\footnotetext{
${ }^{1}$ Pottery was formally analysed at Washington University in St. Louis.
} 
colleagues (Greene and Hartley 2009) to achieve structurally oriented examinations of paste preparation. Pottery, clean clay, and two mudbrick samples received compositional analysis using neutron activation (INAA) ${ }^{2}$ in order to conduct a provenance study. Primary data for this analysis can be found elsewhere (Doumani 2014). Finally, textile-impressions present in pottery fragments further permitted study of perishable fiber technologies.

Faunal remains collected revealed information on herd composition, site-use, and human diet. From the 7,700 fragments found, 1,419 were identified to the lowest possible taxonomic level with both NISP and MNI calculated (Table 2 and 3). Sixteen soil samples were collected and floated for macrobotanical analyses $(\text { Table } 5)^{3}$. Floated soils were subsampled for phytolith analysis and 35 additional soil samples were collected from each occupation phase (Table 6). Onsite and offsite topsoil and subsoil samples were also collected to estimate the current natural phytolith assemblage for the area ${ }^{4}$. The phytolith study also offers us a preliminary measure of the microenvironments and plant resources used around Tasbas in the Bronze Age.

\subsection{Results}

\subsubsection{Tasbas settlement Phase 1 (2832 and 2492 cal B.C.)}

Tasbas Phase 1 dates to the Early Bronze Age. A human cremation interment built alongside a small housing structure documents its earliest period of human activity. Our excavations targeted the cremation feature. This single ritual episode yielded a cist constructed of rectilinear granite slabs approximately 80x $95 \mathrm{~cm}$ in size, oriented NS/EW (Figure 5a, 5b). Cremated contents left a thin deposit of fine ash, charcoal, and burned bone fragments. Low abundance of cremated contents suggests a secondary interment. Beneath the ash we uncovered a compact layer of white clay devoid

\footnotetext{
${ }^{2}$ Neutron Activation Analysis was outsourced to the University of Missouri Research Reactor.

${ }^{3}$ Macrobotanical soil samples were floated in the field then brought to Washington University in St. Louis for examination.

${ }^{4}$ Phytolith samples were analysed at the Institute of Archaeology, University College London.
} 
of charcoal or artifacts that terminated in burned sediment and sterile gravelly fill. In the cist's southeast perimeter an ephemeral lens of ash and burned caprine bones, and at least one larger mammal, was recorded. Three chert microliths and carbonized conifer branches were found in association with this deposit (Figure 5c). The outer northeast boundary of the cist lay beyond the confines of our excavation trench. However, the pilot season (Mar'yashev 2009: Fig. 4) documented a stone-lined circular hearth smeared over with clay in stratigraphic association with our Phase 1. Floated soils taken from the cist interior revealed 25 carbonized seeds, including five grains of freethreshing wheat (Triticum aestivum/turgidum) (Figure 5d; Table 5) (see detail in Spengler et al. 2014a). Two samples of wood charcoal - one from inside and one from outside the cist - and one wheat grain from inside the cist were AMS dated. A weighted average of the three samples was used to yield a 2-sigma range between 2832 and 2492 cal B.C. with the highest probability density (63\%) falling between 2631 and $2562 \mathrm{cal} \mathrm{B.C.} \mathrm{(Table} \mathrm{1).} \mathrm{Two} \mathrm{sterile} \mathrm{fill} \mathrm{layers} \mathrm{ran} \mathrm{across} \mathrm{the} \mathrm{full} \mathrm{extent} \mathrm{of}$ the trench and thoroughly sealed the cultural deposits of Phase 1 from any contamination by later period deposits.

\subsubsection{Tasbas settlement Phase 2a (1416-1287 cal B.C.)}

Fill separating Phase 1 and Phase 2a contained no cultural deposits aside from one decorated potsherd and charcoal fragment AMS dated to the $3^{\text {rd }}-2^{\text {nd }}$ millennium B.C. transition (Table 1). Phase 2 a proper, however, represents the Late Bronze Age (Table 1). Stratified deposits revealed remains of a small circular dwelling ( $3.5 \mathrm{~m}$ across) with stonewall foundations and a clay floor. A central posthole surrounded by multiple smaller postholes suggests a light roof or lean-to sheltered the space. Bones of domesticated and wild fauna, coarseware and decorated pottery, and ground stone tools also belong to this phase. A dense macrobotanical and phytolith assemblage was collected and identified, including, domesticated free-threshing wheat, naked barley (Hordeum vulgare 
var nudum), foxtail millet (Setaria italica) broomcorn millet (Panicum miliaceum), and green peas (Pisum sativum) (Tables 5 and 6). Barley was most abundant in Phase 2a (Table 5). Diverse assemblages of seeds from wild herbaceous plants (Figure 6a-c, e; Tables 5 and 6) were also collected from various cultural features of this phase (see complete macrobotanical report in Spengler et al. 2014b).

Individual hearth features were discovered at both sides of the central post. The first included a fire-pit lined with medium stones coated in clay, much like the satellite fire-pit documented from Phase 1. The Phase 2a fire-pit held ash and carbonized barley grains that spilled over its edge onto the floor. The second hearth feature comprised a clay oven constructed of sunbaked, hand-formed, mudbrick. Its rear portion was embedded in the west bulk wall of trench 2 (Figure 4). The exposed component shows a rectangular structure with side flue that brought oxygen to the inner chamber. Floated contents from the chamber revealed dung, carbonized wood, domesticated and wild plant parts, and burnt bone fragments. A ring of stones that may have served to balance a cooking vessel over the fuel chamber capped the upper bricklayer. One sample of wood charcoal from inside the oven and two barley grains that were embedded in the mudbrick were AMS dated. A weighted average of the three samples yielded a 2-sigma range between 1416 and 1287 cal B.C. (95.4\% probability, Table 1).

\subsubsection{Tasbas settlement Phase 2b (1208-1054 cal B.C.)}

Phase $2 \mathrm{~b}$ represents the Late-Final Bronze Age transition at Tasbas (Table 1). The cultural deposits of Phase 2b contain carbon-rich activity areas with low architectural investment overall. Palimpsests of thin organic deposits and material artifacts lack associated walls or foundations, yet it is possible that parts of the stone foundations from Phase 2a were reused. Ground stone mortars and decorated and plain potsherds from this layer showed little distinction from the Phase $2 \mathrm{a}$ 
deposits. Soil transects were collected across the surface deposits for phytolith studies. A hardpacked carbonate rich deposit divided the deposits of Phase $2 \mathrm{~b}$ and Phase 3.

\subsubsection{Tasbas settlement Phase 3 (930-806 cal B.C.)}

Tasbas Phase 3 represents the Final Bronze Age (Table 1). Ephemeral activity surfaces and hearths are interspersed through thicker layers of cultural fill and suggest punctuated periods of habitation. Construction of a large trash pit suggests inhabitants changed how they used the terrace. Charcoal was collected from a small pit-hearth adjacent to the midden to date this phase (Table 1). The midden comprised burned sediment and clay, ash dumps, charcoal, and unfired fine buttery clay. Coarseware and decorated pottery as well as ground and polished stone implements were present in the deepest midden deposits. Disarticulate stones lined the pit's edge and rammed soil sealed its terminal extent. Unfortunately the pit suffered some anthropogenic disturbance, in the form of intrusive pits and rodent activity during the $18^{\text {th }}-20^{\text {th }}$ century C.E. (Phase 4 , Tasbas). The stratigraphic proximity of the two phases shows around 3000 years of Tasbas's chronology was lost to later clearing or reshaping of the terrace and/or erosion.

\subsection{Discussion}

\subsubsection{Early Bronze Age cremation in Semirech'ye}

Prior to the discovery of an early 3rd millennium B.C. occupation at Tasbas, Begash stood as the earliest settlement in Semirech'ye (Frachetti and Mar'yashev 2007). Begash is located along foothills (950m asl) of the Koksu River valley, approximately $\sim 100 \mathrm{~km}$ southwest of Tasbas. Extant archaeological data from Begash suggest it was used for winter residence. An exciting turn in the discovery of the Tasbas cist, is that Begash (Phase 1a) also yielded a cremation cist and adjacent housing structure (Frachetti et al. 2010b: 1004). The two cists are almost identical in terms of 
construction technique, dimensions and form. Other mutual features include a satellite fire-pit, secondary cremated contents, and carbonized free-threshing wheat in the ash fill.

Noted above, Tasbas phase 1 has a 2-sigma date range of 2631-2562 cal B.C. By comparison, the aggregate AMS dates for the Begash cist fall around 2230-2130 cal B.C. (Frachetti et al. 2010b: Fig. 5), placing the two cremation pits roughly 400 years apart, with Tasbas being earlier. However, by excluding the charcoal and simply comparing the 2 sigma date ranges of the Tasbas wheat (25812468 cal B.C.) (Table 1) and earliest grains from Begash (2460-2150 cal B.C.), the time gap narrows to approximately 200 years. Even so, both cists coincide with the initial occupation phases of both sites and demonstrate longstanding burial tradition of early pastoralists. Along with demonstrating a distinct crematory practice that persists for perhaps 200 years, the deposited grains show a possible geographic route for the spread of wheat into China (see summary in Betts et al. 2014). The funerary practice and structure show no contemporary cases. The nearest parallels are from the 2nd millennium B.C. but they are not identical to our early examples (Kuz'mina 2007: 29, 45; Rogozhinsky 2001:96). The much younger age and altered appearance of the regional samples may allude to the adaption of an earlier ritual construction style for alternate cultural predilections.

\subsubsection{Late Bronze Age and the appearance of mudbrick in Semirech'ye}

Mudbrick from Phase 2a Tasbas is the first incidence of this building material being used in Semirech'ye. In fact, mudbrick constructions of any kind were entirely unknown across much of northern Eurasia prior to the Iron Age (Spengler et al. 2013a). Regionally, mudbricks tempered with cereal straw were used to build ovens at Jeitun (ca. 6000 cal B.C.) in Turkmenistan, over 2500km away (Harris et al. 2013: 332). In the steppes of north-central Kazakhstan, later mudbrick ovens are found at mid- $2^{\text {nd }}$ millennium B.C. Zamaraevo-Alekseevka villages, over $1000 \mathrm{~km}$ away from Tasbas (Sal'nikov 1951:131). The later ovens are interpreted as furnaces for household metal production, 
whereas the rich grain content found in association with the Tasbas oven suggests it more likely served for food preparation. Large geographic and temporal distances separate these examples, and we posit that additional mudbrick features will be found in sites around Tasbas as archaeological research in this region accumulates. For now, the Tasbas oven conveys a regionally isolated example for an innovation in building methods and raw material utilization.

\subsubsection{Microenvironment and land use at Tasbas}

The phytolith study offered a preliminary measure of the use of plant resources originating from distinct microenvironments near Tasbas. It is important to bear in mind that these data are derived from depositions of anthropogenic origin and is therefore likely to reflect changes in land use and the environment (including climate). The degree to which these two variables are represented in this dataset is difficult to determine using the phytolith data alone. Two climatic indices were calculated for each occupation phase using single cell morphotypes of phytoliths that are particular to the Pooid, Panicoid and Chloridoid subfamilies of grasses (Figure 7d-e) (Twiss et al. 1969). Pooid grasses have a C3 photosynthetic pathway, and generally are adapted to cool season growth in wet or dry environments (Twiss et al. 1987). Wheat, barley, oats and rye all belong to the Pooidiae subfamily. Panicoid grasses mostly have a C4 photosynthetic pathway, and are adapted to warm or hot seasonal conditions in moist or dry environments (Twiss et al. 1987). Both Panicum miliaceum and Setaria italica belong to the Panicoidiae subfamily. Chloridoid grasses also have a C4 photosynthetic pathway, and like Panicoid grasses are adapted to warm or hot seasonal conditions, but they often tolerate lower soil moisture availability than Panicoid grasses (Twiss et al. 1987), and are therefore useful in indicating relative aridity (Piperno 2006:32-34; Rosen 2001: 187; Strömberg 2009). In addition, the ratio of phytoliths from woody dicotyledonous plants versus those from 
grasses was calculated (Figure 8). Ratios and indices were calculated after Bremond and colleagues (2008):

Climatic Index:

Ic $(\%)=($ Pooid morphotypes $/$ Pooid + Panicoid + Chloridoid morphotypes $) \times 100$

Woody dicotyledon/Grass ratio:

$\mathrm{D} / \mathrm{P}^{\circ}=$ Woody dicotyledonous morphotypes / grass morphotypes

Aridity Index:

Iph $(\%)=($ Chloridoid morphotypes / Chloridoid + Panicoid morphotypes $) \times 100$

Climatic index (Ic) indicates a trend towards increasing exploitation of warmer environments from Phases 1 to 2b, with a return to cooler environments in Phase 3 (Figure 8a). Ratio of phytoliths from woody dicotyledonous plants to those from grasses $\left(\mathrm{D} / \mathrm{P}^{\circ}\right)$ fell from Phase 1 to Phase 3 (Figure 8b), while the aridity index (Iph) indicates increasing presence of dry-adapted grasses at Tasbas over the same period (Figure 8c). These calculations may reflect an actual increase in aridity through time, accompanied by a reduction in tree cover. If so, wood available for fuel and construction may have declined as well. Alternatively, a changing pattern of land use possibly occurred within a stable climate. The lower presence of woody plants in later phases may therefore reflect new choices in grazing practices, dung burned more often for fuel, and changes in plant types exploited for construction and craft.

The macrobotanical wild seed in the macrobotanical assemblage (Table 5) contains a prevalence of low-growing herbaceous plants, which have been associated with the remains of dung burning elsewhere in central Eurasia (Miller 1996; Spengler 2013b). These results raise questions about the relationship among grazing, fuel choices, and climate, and the effect these forces have on the landscape. In addition to the evidence for dung burning, phytoliths from the common reed 
(Phragmites australis) were present across floor contexts and in post-hole deposits of Phase 2a (Figure 7f). Today, reeds grow in abundance along the riverbank and surrounding marshlands by Tasbas. Bronze Age herders may have used marshland plants, like reeds, for fodder, craft production, roofing and floorcoverings from Phase $2 \mathrm{a}$ onward. Such uses have been recorded historically on the steppe (Anthony et al. 2005:406; Masanov 1995: 392) and can still be observed in the region today (personal observation). Dung remains at Tasbas offer data supporting a shift in fuel use away from wood, towards the exploitation of drier, less woody upland environments and lowland marshes throughout the Bronze Age.

\subsubsection{Late-Final Bronze Age pottery from Tasbas}

Pottery culture-histories comprise the traditional and principal means of reconstructing prehistoric society and economy in Semirech'ye (Gor'yachev 2004, Kuz'mina 1970). By contrast, pottery technology has not been explored systematically, despite what it can tell us about the social context in which potting occurred and its relationship to the broader economy. The style and technical elements of the Tasbas ceramics from phases $2 \mathrm{a}, 2 \mathrm{~b}$, and 3 were examined toward this end. Phase 1 cultural deposits revealed no pottery remains.

Visual inspection of the radiographs and potsherds found low-density, coarse fabrics containing poorly levigated angular inclusions (Figure 9f-g). Two broad paste groups were discernable: 1) primarily granite; and 2) roughly equal amounts of granite and sand. Dung and straw temper is present in moderate amounts across both groups (Figure 9i). Exposed piece-joins, finger indentations, and rim seams are of a nature that advocates pots were handmade using composite slab-coil or slab-mold construction (Figure 9a-b). Double-layered slab building predominates among bodies and bases, whereas rims received single layered slabs or coils. This building style is true of most pottery from the complete dataset. Textile and defined finger imprints on alternating sides of 
body sherds from Phase $2 \mathrm{~b}$ and 3 show the supplementary use of textile-lined convex molds (Figure 9c-e). Both coarsely and finely manufactured plain-weave interlace and hand-twined textiles exist in the impressions. Cloth-impressions offer a glimpse into the rarely encountered weaving tradition of Bronze Age pastoralists in Semirech'ye (Doumani and Frachetti 2012), and among regional pastoralists, hunter-gatherer and agricultural communities alike (see examples in Chernai 1985; Gulyamov 1966; Loman 2004; Korobkova 1962; Kupriyanova 2008). For example, the documented set of weave styles suggests the Tasbas inhabitants incorporated numerous raw sources, and/or processing techniques into their fiber-based crafts. The junction between textile and ceramic industries is just one illustration of how different material crafts and technologies intersected at Tasbas.

A second instance is found in the pottery and mudbrick from Tasbas phase 2a. The two object classes are visually alike based on texture, color, and inclusion type. Compositional analysis of the potsherds and mudbrick further revealed high correlation in element composition, which implies local production of ceramics and mudbricks alike (Doumani 2014). Round flat stones for shaping pot bases, modified animal bones to thin and decorate walls, and smooth river pebbles to assist burnishing were other finds that further support onsite potting at Tasbas. Warm, dry weather is essential for potting (Arnold 1985: 99). Thus, at Tasbas, groups likely used the summertime to make pottery (and mudbrick) when clays and harvest waste were easier to obtain and air-drying prior to firing would occur most rapidly. Firings were likely of short duration with temperatures that rose and fell quickly. Vessel surfaces display mottled colors, large surface fractures around granite inclusions (Figure 9h), and diffuse cores from organic components not fully carbonizing - all typical results of rapid firings in open pits (Rye 1981:110-116; Sillar 2000:47). These qualities, in addition to the limited levigation of clays and time efficient building outlined already, suggest a narrow time window for potting in general. 
The production steps outlined above accomplished both plain coarsewares and decorated pottery similar to regional potteries (e.g., Demin and Sinikov 2002; Jai et al. 2009; Loman 1987). The Tasbas coarsewares and decorated pots include medium size (approx. $20 \mathrm{~cm}$ rim diameter) robust jars with thick walls $(7-11 \mathrm{~mm})$, restricted orifices, and high, rounded shoulders that narrow and straighten toward the base (Figure 10a-c). Long-term continuity in production techniques, however, is offset by slight temporal changes in vessels ornamentation. Phase $2 \mathrm{a}$ and $2 \mathrm{~b}$ pots are stamped with pronged instruments, or adorned with clay appendages in the form of lugs or horizontal bands (Figure 10d). In Phase 3 incising is prevalent even though stamping and applique methods continue (Figure 10e).

\subsubsection{Faunal assemblage and habitation seasons at Tasbas}

The Tasbas zooarchaeological assemblage contains well-preserved, yet highly fragmented, bones. The mean length of an identified fragment was $5 \mathrm{~cm}$, and is fairly consistent between phases (smallest mean: phase 3 at $4.5 \mathrm{~cm}$, largest mean: phase 4 at $5.5 \mathrm{~cm}$ ). Six domesticated taxa were identified: sheep, goat, cattle, horse, ass, and camel. The bulk of specimens ( $92 \%)$ for the Bronze Age represent domesticated fauna from sheep, goat, cattle, and horse (see Table 2 and Table 3 for breakdown by phase). The Tasbas faunal record is similar to those obtained for lower elevation winter campsites in Semirech'ye like Begash (Frachetti and Benecke 2009; Frachetti et al. 2010a), unsurprising given that regional groups are believed to have seasonally migrated with their herds across this piedmont zone.

Bones of domestic and wild species were recovered from every occupation phase. Although domestic species dominate the faunal remains at Tasbas, supplemental amounts of animal protein were also obtained from gazelle, deer, and fish ${ }^{5}$. Of the total 1,419 identified fragments, 95 (about 7\%) had some degree of burning, and 129 (about 9\%) had modifications that would indicate

\footnotetext{
${ }^{5}$ A fish spine was recovered from floated soils from Phase $2 \mathrm{a}$.
} 
butchery. Table 4 includes counts by phase. In phase $2 \mathrm{~b}$, butchered bones of antelope, sheep, and goat include all components of the skeletons, indicating on-site butchering. In the Bronze Age assemblage, neither ass, camel, nor horses exhibited butchering marks, thus they may have served as pack animals for excursions to obtain clays or other raw materials for craft production, or for seasonal migrations.

The animal remains are unevenly distributed over the phases, which limits what we can say about changing trends in butchery and diet practices at the site. However, some information can be taken away from Table 4 that may in fact reflect shifting use of the terrace over time as groups returned periodically. For Phase 1, although the total NISP is quite low, the butchered specimens represent a high percentage. Concentration of butchered bones alongside the cremation cist may relate to the ritual's performance. The later occupation deposits contain higher total NISP, but a lower percentage of butchered specimens, which we propose is a reflection of activities that took place on the terrace. The proportion of butchered specimens increases from phase $2 \mathrm{a}$ into $2 \mathrm{~b}$, and then 3. Excavation of Phase 2a captured the internal area of the house only, whereas excavations of the later phases found outdoor areas - where butchering and processing more likely occurred.

Complete herds were kept as shown by the presence of neonate, sub-adult, and adult domesticates. On the basis of epiphyseal fusion and dental wear (Grant 1982) some animals were identified as being several years old (Figures 11a-b). The reader will note that our overall numbers are quite low. Thus, while it is possible to demonstrate the presence of sub-adult animals, a robust reconstruction of herd composition is not possible at this point, and the fauna presented here cannot provide evidence of seasonality of occupation. While other Late Bronze Age settlements provide evidence for seasonal herding strategies, analysis of cementum annulations in the caprine teeth from Tasbas provides one the first known cases for year-round occupation (unpublished results) and the osteological information seems to support this idea. For example, identification of a 
neonate caprine in phase $2 \mathrm{~b}$ is evidence of at least occasional spring/winter habitation at Tasbas. Sub-adult caprines also indicate habitation in the summer when nutrient rich grasses are abundant for grazing, through crop harvesting, and then into the winter. Finally, little pathology was found that would suggest poor grazing conditions for the animal population, so if groups did remain into the colder months, it may have been during years with higher summer precipitation or milder weather that would allow for longer stays with a consequent reduction in seasonal mobility. Ethnographic accounts (e.g., Vainshtein 1980:158) of Eurasian mobile herders describe the transition to farming sometimes depended on having healthy abundant herds suitable for draught labor. The appearance of horse and ass in Phase $2 \mathrm{~b}$ may have facilitated this economic shift and eased the labor needs associated with cultivation, which we turn to now.

\subsubsection{Bronze Age cereal cultivation at Tasbas}

Both archaeobotanical research methods identified five domestic crops at Tasbas (Table 5 and 6). These crops would require precise scheduling in order to achieve economic success. The crop cycles would require at least some people to be present during the spring/summer (Vainshtein 1980: 149-151; Irons 1975: 158; Masanov 1995: 394) even if groups resided at the settlement for a more extended period. Moreover, these crops are known to respond differently to vast fluctuations in grassland coverage, precipitation, and weather conditions along mountain-steppe zones of Eurasia and they all require different labor needs. The individual strengths and requirements of each plant may have increased crop security and given mobile sectors of the population greater flexibility during wet or dry years (see section 1.4.3).

Macrobotanical samples from Phase 1 revealed wild grasses and wheat grains (Table 5). The Phase 1 phytolith sample lacked phytoliths from wheat husks, which may suggest only clean grain was present for this early period (Table 6). The unique context of the wheat grains from Phase 1 at 
Tasbas (a cremation burial, similar to contemporaneous finds of grains at Begash) and the lack of corollary phytolith evidence for chaff, leave the economic significance of this find unresolved. By contrast, phytolith and macrobotanical data sets from Phase 2a onward provide a robust picture of the economy - one that points to the emergence of mixed economies at higher elevations who employed both herding and crop cultivation.

Examination of mudbricks from the oven feature, under high magnification, revealed wellpreserved carbonized barley grains and barley rachis impressions, as well as voids in the shape of stems and culms presumed to be from decomposed straw (Figure 6f-g). Floated soils from the mudbrick (Macrobotanical Samples FS22 and FS19, Table 5) similarly revealed carbonized barley grains and rachises (Figure 6c, d). In addition, phytoliths of barley husks were identified as well as single-celled phytoliths from grass leaves/culms, indicating that the whole barley plant may have been used as temper (Figure 6h). Organics would have served as binders and these were used in combination with a very coarse $(>2 \mathrm{~mm})$ granite temper that would aid thermal efficiency. The chemical composition, fabric structure, and paste contents of the mudbrick and some Phase 2a pottery are alike (Doumani 2014), which shows the integration of this basic recipe across multiple craft occupations.

Along with barley, phytoliths from the husks of foxtail and broomcorn millet and wheat were identified in the floor and hearth contexts from Phases 2a onward (Table 6), along with phytoliths from grass leaves/culms. A soil transect taken from an ephemeral surface in phase $2 \mathrm{~b}$ revealed phyotliths from the husk of foxtail and broomcorn millet and wheat in addition to single cell phytoliths from grass leaves/culms (Figure 7a-7c). The concentration and relative ratio of the two plant parts declined across the floor in a pattern that suggests plants were processed in this area or debris was swept to one side of a workspace. The ephemeral, architecturally void deposits of Phase $2 \mathrm{~b}$ may describe an outdoor space where messy activities such as crop processing and animal 
butchering (section 1.4.5) were performed away from the dwelling. Soils collected from Phase 3 similarly revealed multi-celled phytoliths from wheat and millet husks, suggesting crop processing continued on this area of the terrace (Figure $7 b, 7 c)$.

The nature of plant remains at Tasbas confirm a multi-crop assemblage was grown nearby and processed on-site starting in the mid- $2^{\text {nd }}$ millennium B.C. Discovery of local cultivation of multiple crops in a region where the earliest farming was previously dated approx. 1000 years later (Spengler et al. 2013a), implores the question of how crops and knowledge for successful cultivation developed at the site? In total, the floated soils revealed over $90 \%$ ubiquity, high abundance, and high density of domestic grains (Spengler 2014b: Table 2); ratios that are on par with later agricultural villages (Spengler et al. 2013a; Lebedeva 2005). Populations living at Tasbas in the mid$2^{\text {nd }}$ millennium B.C. invested in a mixed economy that incorporated herding, hunting, and farming, which provides nuance in understanding the diverse economy practiced by these groups. However, no storage areas, pits, or large storage vessels were found at Tasbas. Lack of evidence for significant production of grain suggests that farming at this stage was not intensive enough for surplus grain to be stored for later use. The Bronze Age campsites in the Bayan-Zhurek valley are both small and disaggregated, differentiating them structurally and functionally from later farming hamlets of the Iron Age in Semirech'ye (Spengler et al. 2013a). While Tasbas now offers the first unequivocal example for $2^{\text {nd }}$ millennium $\mathrm{BC}$ farming in northern Central Asia, we await further work to understand how pervasive or intensive it was throughout the region.

\subsection{Conclusion}

In this paper we offered descriptions and interpretations of the seasonal economy, and domestic and ritual practices of highland mobile pastoralists in Kazakhstan. We focused on the pastoral campsite Tasbas where we find that both stability and innovation were important 
characteristics of local community activity and behavioral transitions for over 2000 years of the Bronze Age. Multiple data sets allowed us to address how the site was used, the possible interaction and effects of humans on the environment, and to further understand the varied and nuanced elements of the economy from the $3^{\text {rd }}$ to $1^{\text {st }}$ millennium B.C.

We identified a new regional tradition of cremation ritual dating to the mid- $3^{\text {rd }}$ millennium B.C. The Early Bronze Age cremation cist documents the earliest evidence for pastoral habitation as well as the local use of domesticated wheat in Semirech'ye. The nearly identical cist structure and associated contents approx. 200 years later at Begash illustrates a long-term burial tradition that may index deliberate investments in discrete locales by the region's first pastoralists.

Phytolith data provided a preliminary view into possible changes in climate across the $3^{\text {rd }}-$ $1^{\text {st }}$ millennium B.C., as well as how humans interacted with their natural environment. The faunal assemblage showed healthy herds of all ages were kept at the site. Drawing from data presented here on the age structure of the animal domesticates, we propose that groups stayed at the settlement beyond the spring/summer season. Finally, mobility may have been assisted by the use of pack animals and protein was obtained primarily from domesticated animals as opposed to wild species.

Ceramics were locally produced with long-term continuity in manufacture techniques across eight centuries (approx. 1500-800 B.C.). This technical conservancy was coupled with paste preparation, vessel building, and firing procedures that all point toward expedient and seasonal production during the summer months, even if groups remained at the site into the colder periods of year. Lastly, potting clays and mudbrick shared chemical composition. We speculate that this intersection between two areas of craft production developed out of a dietary shift and incorporation of grain farming in the mid- $2^{\text {nd }}$ millennium B.C. that stimulated new methods and equipment for food preparation. Preexisting knowledge of clay sources and paste recipes may have offered a convenient jumping point for implementing such change. 
Finally, we presented the first evidence for farming (mid- $2^{\text {nd }}$ millennium B.C.) in northern Central Asia. Our Late Bronze Age domesticated grain assemblage documents local cultivation and processing at Tasbas. We argue this based on an abundance of domesticated crop phytoliths, a high density of domesticated grains, abundance of barley rachises, use of a barley straw binder in mudbrick construction, and through the presence of five crop types. The grain assemblage documents both the eastward and westward spread of staple crops across Eurasia.

Situated in the mountains spanning the regions between the sedentary agricultural centers of China and southern Central Asia, sites like Tasbas were ideally situated to facilitate the broad scale transmission of any number of innovations during this formative period. In adding to the model of non-uniform complexity (Frachetti 2012), we suggest that central Eurasian populations returned repeatedly to ecological niches they understood well, of which facilitated long-term survival of a broadly defined pastoral economy. Yet this longevity was offset by the adaption and integration of new and novel practices into ritual and day-to-day behaviors - whether emerging in the operational steps of potting, or as shifts in diet and subsistence. To conclude, research at Tasbas has shown that even this tiny settlement in a vast and under-explored landscape has the potential to answer questions about wide-scale interactions as well as the persistence of local communities of practice. Future research at habitation contexts across the region will allow a fuller and more detailed picture to emerge about the formation of Eurasian communities and about the mechanisms and nature of exchange in knowledge and goods across the Old World.

\section{Acknowledgements}

This work was supported by the NSF Grants 1132090, 0535341, 1010678; Lambda Alpha National Honor Society; Wenner-Gren Grant 8503; The Arts and Humanities Research Council (UK), and Washington University in St Louis. 


\section{References Cited}

Anthony, D. W., 2008. The Horse, the Wheel, and Language: How Bronze-Age Riders from the Eurasian Steppes Shaped the Modern World. Princeton, Princeton University Press.

Anthony, D. W., 2013. Two IE phylogenies, three PIE migrations, and four kinds of steppe pastoralism. Journal of Language Relationship: International Scientific Periodical 9:1-21.

Anthony, D.W., Brown, D., Brown, E., Goodman, A., Kokhlov, A., Kosintsev, P., Kuznetsov, P., Mochalov, O., Murphy, E., Peterson, D., Pike-Tay, A., Popova, L., Rosen, A., Russel, N., Weisskopf, A., 2005. The Samara Valley Project. Eurasia Antiqua 395-417.

Arnold, D.E., 1985. Ceramic Theory and Cultural Process. New York, Cambridge University Press. Baipakov, K.M., Mar'yashev, A.N., 2008. Byan-Zhurek Petroglyphs. Credo, Almaty, Kazakhstan.

Bendrey, R., 2011. Some like it hot: environmental determinism and the pastoral economies of the later prehistoric Eurasian steppe. Pastoralism: Research, Policy and Practice 1(1):8.

Betts, A., Jia, P., Dodson, J., 2014. The origins of wheat in China and potential pathways for its introduction: A review. Quaternary International 348:158-168.

Bremond, L., Alexandre, A., Wooller, M.J., Hély, C., Williamson, D., Schäfer, P.A., 2008. Phytolith indices as proxies of grass subfamilies on East African tropical mountains Global and Planetary Change 61 (3): 209-224. 
Bronk Ramsey, C., 2009. Bayesian analysis of radiocarbon dates. Radiocarbon, 51(1), 337-360.

Chernai, I.L., 1985. Tekstil'noe delo i keramika po materialam iz pamytnikov Eniolit-Bronzy yuzhnogo aural'ya ksevernogo Kazakhstana. The Eneolithic and Bronze Ages between the Ural and Irtysh Rivers. Chelyabinsk, Cheglu.

Demin, M.A., Sinikov, C.M., 2002. Poselenie Chekanovskiy Logv Sisteme Otnositel'noy Khronologii Sargarinsko-Alekseevskikh Drevnostey. Northern Eurasia In The Bronze Age: Space, Time, Culture. Barnaul, Altai University, pp. 29-36.

Doumani P.N., 2014. Bronze Age Potters in Regional Context: Long-term Development of Ceramic Technology in the Eastern Eurasian Steppe Zone. Unpublished doctoral dissertation. Department of Anthropology, Washington University in St. Louis. United States.

Doumani, P.N., Frachetti, M.D., 2012. Bronze Age textile evidence in ceramic impressions: weaving and pottery technology among mobile pastoralists of central Eurasia, Antiquity 86:368-382.

Frachetti, M.D., 2012. Multiregional Emergence of Mobile Pastoralism and Nonuniform Institutional Complexity across Eurasia. Current Anthropology 53(1) 2-38.

Frachetti, M.D., 2011. Migration Concepts in Central Eurasian Archaeology. Annual Review of Anthropology 40:195-212.

Frachetti, M.D., 2008. Pastoralist Landscapes and Social Interaction in Bronze Age Eurasia. Berkeley, 
University of California Press.

Frachetti, M.D., Benecke, N., Mar'yashev, A.N., Doumani, P.N., 2010a. Eurasian Pastoralists and their shifting regional interactions at the steppe margin: settlement history at Mukri, Kazakhstan. World Archaeology 42 (4):622-646.

Frachetti, M.D., Spengler, R.N., Fritz, G.J., Mar'yashev, A.N., 2010b. Earliest direct evidence for wheat and millet in the central Eurasian Steppe Region. Antiquity 84: 993-1010.

Frachetti, M.D., Benecke, N., 2009. From sheep to (some) horses: 4500 years of herd structure at the pastoralist settlement of Begash (south-eastern Kazakhstan). Antiquity 83:1023-1037.

Frachetti, M.D., Mar'yashev, A.N., 2007. Long-Term Occupation and Seasonal Settlement of Eastern Eurasian Pastoralists at Begash, Kazakhstan. Journal of Field Archaeology 32: 221-242.

Gor'yachev, A.A., 2004. The Bronze Age Archaeological Memorials in Semirech'ye. In: Linduff, K. (Ed.), Metallurgy in Ancient Eastern Eurasia from the Urals to the Yellow River. Lewiston, NY, Edwin Mellen Press, pp. 109-152.

Grant, A., 1982. Use of tooth wear as a guide to the age of domestic ungulates, BAR British Series 109: 91 108.

Greene, A.F., Hartley, C.W., 2009. From Analog To Digital: Protocols And Program For A Systematic Digital Radiography Of Archaeological Pottery, Vessels Inside and Outside: Proceedings of the Conference 
EMAC '07 9th European Meeting on Ancient Ceramics, 24-27 October 2007, Hungarian National Museum.

Gulyamov, Y.G., Islamov, U., Askarov, A., 1966. Pervobytnaya Kul'tura i Vozniknovenie Oroshaemogo Zemledeliya v Nizov'yakh Zarafshana. Tashkent, Academy of Sciences, SSR Uzbekistan: Fan.

Hanks, B. K., Doonan, R., 2009. From Scale and Practice: A New Agenda for the Study of Early Metallurgy on the Eurasian Steppe. Journal of World Prehistory 22:329-356.

Hanks, B. K., Linduff, K. 2009. Social Complexity in Prehistoric Eurasia: Monuments, Metals, and Mobility. Cambridge, Cambridge University Press.

Harris, D.R., Masson, V.M., Berezkin, Y.E., Charles, M.P., Gosden, C., Hillman, G.C., Kasparov, A.K., Korobkova, G.F., Kurbansakhatov, K., Legge, A.J., Limbrey, S., 1993. Investigating early agriculture in Central Asia: new research at Jeitun, Turkmenistan. Antiquity 67:324-338.

Irons, W., 1975. The Yomut Turkmen: A study of social organization among Central Asian Turkic-speaking populations. Ann Arbor, The University of Michigan.

Jia, P., Betts, A., Wu, X., 2009. Prehistoric Archaeology in the Zhunge'er (Junggar) Basin, Xinjiang, China. Eurasian Prehistory 6(1-2): 167-198.

Korobkova, G.F. 1962. Otpechatki tkaney na keramike (po materialam Dal'verzina Eylatana i Daraut Kurgana). Materialy i Issledovaniya po Arkheologii SSSR, 118:231-234.

Koryakova, L., Epimakhov, A. V., 2007. The Urals and Western Siberia in the Bronze and Iron Age. 
Cambridge, Cambridge University Press.

Kupriyanova, E., 2008. Ten' Zhenshchiny Zhenskiy Kostyum Epokhi Bronzy kak tekst. Chelyabinsk, Avto Graf.

Kuz'mina, E.E., 2007. The Origin of the Indo-Iranians. Brill, Leiden Indo-European Etymological Dictionary Association.

Kuz'mina, E.E., 1970. Semiechenskiy variant kul'tury Pozdney Bronzy. Kratkie Soobshcheniya, Academy of Sciences CCCP 122.

Lebedeva, E., 2005. Archaeobotany and studies of Bronze Age agriculture in Eastern Europe. Opus: Mezhdistsiplinarnye Issledovaniya v Arkheologii 4:50-68.

Loman, V.G., 2004. Goncharnaya Tekhnologiya Nekotorykh Andronovskikh Poseleniy Tsentral'nogo Kazakhstana. Questions on the History and Archaeology of Western Kazakhstan. Uralsk, Western Kazakhstan Oblast Center for History and Archaeology, pp. 353-359.

Loman, V.G., 1987. Voprotsy Periodizatsii Arkheologicheskikh Pamyatnikiov Tsentrali'nogo i Severnogo Kazakhstana, Karaganda, Karaganda State University, pp. 115-129.

Mar'yashev, A.N., 2002. Novye Materialy o Poseleniyakh Epokhi Bronzy v Gorakh Bayan Zhurek. Izvestiya 1(236): 23-30. 
Masanov, N., 1995. Northern Areas (Transoxania and the Steppes) Pastoral Production. In: Baipakov, K.M., Moosvi, S., Burton, A. (Eds.) History of Civilizations of Central Asia: Development and Contrast from the Sixteenth to the Mid-nineteenth Century. UNESCO Publishing, pp. 373-375.

Mei, J., 2009. Early Metallurgy and Socio-Cultural Complexity: Archaeological Discoveries in Northwest China. In: Hanks B. K., and Linduff, K. (Eds.), Social Complexity in Prehistoric Eurasia: Monuments, Metals and Mobility. Cambridge, Cambridge University Press, pp. 215-232.

Miller, A.V., Usmanova, E., Logvin, V., Kalieva, S., Shevnina, I., Logvin, A., Kolbina, A., Suslov, A., Privat, K., Haas, K., Rosenmeier, M., 2014. Subsistence and Social Change in Central Eurasia: Stable Isotope Analysis of Populations Spanning the Bronze Age Transition. Journal of Archaeological Science 42:525-538.

Miller, N.F., 1996. Seed Eaters of the Ancient Near East: Human or Herbivore? Current Anthropology 37(3): 521-528.

Murphy, E.M., Schulting, R., Beer, N., Chistov, Y., Kasparov, A., Pshenitsyna, M., 2013. Iron Age pastoral nomadism and agriculture in the eastern Eurasian steppe: implications from dental palaeopathology and stable carbon and nitrogen isotopes. Journal of Archaeological Science 40 (5): 2547-2560.

Panyushkina, I.P., Chang, C., Clemens, A.W. Bykov, N., 2010. First tree-ring chronology from Andronovo Archaeological Timbers of Bronze Age in Central Asia. Dendrochronology 28: 13-21.

Piperno, D. R., 2006. Phytoliths: A Comprehensive Guide for Archaeologists and Paleoecologists. Oxford, AltaMira Press. 
Reimer, P. J., Bard, E., Bayliss, A., Beck, J. W., Blackwell, P. G., Bronk Ramsey, C., Grootes, P. M., Guilderson, T. P., Haflidason, H., Hajdas, I., Hatt, C., Heaton, T. J., Hoffmann, D. L., Hogg, A. G., Hughen, K. A., Kaiser, K. F., Kromer, B., Manning, S. W., Niu, M., Reimer, R. W., Richards, D. A., Scott, E. M., Southon, J. R., Staff, R. A., Turney, C. S. M., \& van der Plicht, J., 2013. IntCal13 and Marine13 Radiocarbon Age Calibration Curves 0-50,000 Years cal BP. Radiocarbon, 55(4).

Reitz, E.J., Wing. E.S., 2008. Zooarchaeology, 2nd edition. Cambridge University Press, Cambridge. Rogozhinsky, A. R., 2011. Tamgaly. Almaty.

Rosen, A., 2001. Phytolith evidence for agropastoral economies in the Scythian period of southern Kazakhstan. In: Meunier, J.D., Colin. F. (Eds.) The Phytoliths: Applications in Earth Science and Human History. Aix en Provence, CEREGE, pp. 183-198.

Rouse, L. M., Cerasetti, B., 2013. Ojakly: A Late Bronze Age mobile pastoralist site in the Murghab Region, Turkmenistan. Journal of Field Archaeology 39:1-19.

Rye, O.S., 1981. Pottery Technology: Principles and Reconstruction. Washington, Taraxacum.

Sal'nikov, K.V., 1951, Bronzovyy Vek Yuzhnogo Zaural'ya. Materials and Research in Archaeology of the USSR, 21:94-151.

Sillar, B., 2000. Dung by Preference: The choice of fuel as an example of how Andean pottery production is embedded within wider technical, social, and economic practices. Archaeometry 42:43-60. 
Spengler, R.N., Chang, C., Tourtellotte, P.A., 2013a. Agricultural production in the Central Asian mountains: Tuzasai, Kazakhstan (410-150 B.C.). Journal of Field Archaeology 38 (1): 68-85.

Spengler, R.N., Frachetti, M.D., Fritz, G.J., 2013b. Ecotopes and Herd Foraging Practices in the Bronze and Iron Age, Steppe and Mountain Ecotone of Central Asia, Journal of Ethnobiology 33 (1): 125-147.

Spengler, R., Frachetti, M., Doumani, P., Rouse, L., Cerasetti, B., Bullion, E., Mar'yashev, A., 2014a. Early Agriculture and crop transmission among Bronze Age mobile pastoralists of central Eurasia. Proceedings of the Royal Society B. 281, 20133382.281.

Spengler, R.N., Frachetti, M.D., Doumani, P.N., 2014b. Agriculture in the Piedmont of Eastern Central Asia: The Late Bronze Age at Tasbas, Kazakhstan. Quaternary International 348:147-157.

Strömberg, C. A. E., 2009. Methodological concerns for analysis of phytolith assemblages: Does count size matter? Quaternary International 93:124-140.

Twiss, P.C., Dort Jr., W., Sorenson, C.J., 1987. Grass-opal phytoliths as climatic indicators of the Great Plains Pleistocene. Quaternary Environments of Kansas, Guidebook Series Kansas Geological Survey 5: 179-188.

Twiss, P.C., Suess, E., Smith, R.M., 1969. Morphological classification of grass phytoliths. Procedure of Soil Science Society of America 33: 109-115.

Vainshtein, S. Y., 1980. Nomads of South Siberia the Pastoral Economies of Tuva. M. Colenso, transl. 
Cambridge: Cambridge University Press 1980.

\section{Figure Captions}

Figure 1. Map of Semirech'ye showing the Dzhungar Mountains with location of Tasbas

Figure 2. Natural setting around Tasbas, Byan-Zhurek Valley, Semirech'ye

Figure 3. Excavation trenches from 2001 and 2011 seasons at Tasbas

Figure 4. Excavation profiles Tasbas: a) trench 1; b) trench 2

Figure 5. Early Bronze Age Tasbas Phase 1: a) stone-lined cremation cist showing ash and clay deposits; b) excavated cist; c) two chert microliths deposited alongside cist; d) two free-threshing wheat grains recovered from floated soils (sample FS30) collected from inside the cist.

Figure 6. Late Bronze Age, Phase 2a Tasbas. Items recovered from oven floatation sample: a) broomcorn millet grain; b) green pea; c) naked barley grain; d) barley rachis; e) free-threshing wheat grain. Details of mudbrick from phase 2a domestic oven showing: f) barley impression in mudbrick;

g) voids from straw-temper in the mudbrick; h) Multi-celled phytolith from barley husk (Hordeum vulgare) in mudbrick sample.

Figure 7. Phytoliths from Tasbas. Multi-celled silica skeletons and single-celled morphotypes: a) multi-celled phytolith husk of wheat (Triticum aestivum/turigidum); b) multi-celled phytolith from husk of Broomcorn millet (Panicum miliaceum); c) cross-shaped phytolith from Foxtail millet (Setaria italica); d) saddle-shaped phytolith occurring in C4 grasses; e) multi-celled phytolith from the leaf or stem of a panicoid grass showing bilobate and elongate psilate phytoliths; f) multi-celled phytolith from the leaf or stem of the common reed (Phragmites australis).

Figure 8. Climatic Indices for Tasbas Phase 1 through Phase 3 using phytolith data: a) Climatic Index (Ic) per occupation phase; b) ratio of woody dicotyledonous plants versus grasses $\left(\mathrm{D} / \mathrm{P}^{\circ}\right)$; c) Aridity Index (Iph) at Tasbas from Phase 1 to Phase 3. 
Figure 9. Tasbas pottery from Late and Final Bronze Age: a) slab break in vessel wall indicated by black arrows; b) double-slab in vessel base indicated by black arrows. Alternating sides of body sherd hosting: c) finger prints indicated by dashed circle; d) textile-impression on opposite facing side; and, e) and mold taken of the weave structure left by the original textile; $f$-g) digital radiographs of rim sherds showing coarse fabric, vegetal voids (appearing as white) and granite inclusions (appearing as black); h) surface fractures around coarse granite inclusions; i) voids in ceramic fabric from burned out organics.

Figure 10. Tasbas pottery: $a-c)$ Coarseware vessels from phase $2 \mathrm{a}, 2 \mathrm{~b}$ and 3 represented by rims and base fragments; d) Late Bronze Age decorated pottery (phases 2a/2b); e) Final Bronze Age decorated pottery (phase 3).

Figure 11. Age profiles for Tasbas faunal assemblage: a) Age profiles for Bos taurus. U is unfused; F is fused. The early, middle and late fusing categories are based on Reitz and Wing (2008:72). Early fusing are fused within the first year and a half to two years; middle fusing are within the first three years; late fusing are within four or five years; b) Age profiles for caprines (includes caprines, $C$. bircus, and O. aries). $\mathrm{U}$ is unfused; $\mathrm{F}$ is fused. Early fusing are fused within the first year and a half to two years; middle fusing are within the first three years; late fusing are within four or five years. 
Table 1: Calibrated ranges (B.C.) of AMS dates from Tasbas with corresponding archaeological phases. Calibration curve IntCal 13 (Reimer et al. 2013)

\begin{tabular}{|c|c|c|c|c|c|c|c|}
\hline \multirow{2}{*}{$\begin{array}{l}\text { Archaeological } \\
\text { Phase at Tasbas }\end{array}$} & \multirow[t]{2}{*}{ Lab. Index } & \multirow[t]{2}{*}{ Material } & \multirow[t]{2}{*}{ Date B.P. } & \multicolumn{2}{|c|}{ Calibrated Date B.C. } & \multicolumn{2}{|c|}{$R_{\text {_combined }} * *$} \\
\hline & & & & $68.2 \%(1 \sigma)$ & $95.4 \%(2 \sigma)$ & $68.2 \%(1 \sigma)$ & $95.4 \%(2 \sigma)$ \\
\hline Phase 1 & OS-93050* & wood charcoal & $4100 \pm 30$ & $\begin{array}{l}2840-2814 \\
2678-2578\end{array}$ & $\begin{array}{l}2862-2806 \\
2758-2717 \\
2707-2570 \\
2513-2503\end{array}$ & $\begin{array}{l}2620-2568(51 \%) \\
2516-2500(17.2 \%)\end{array}$ & $\begin{array}{l}2832-2820(2.8 \%) \\
2631-2562(63.7 \%) \\
2534-2492(29 \%)\end{array}$ \\
\hline Phase 1 & OS-93054* & wood charcoal & $4060 \pm 30$ & $\begin{array}{l}2831-2821 \\
2630-2565 \\
2525-2496\end{array}$ & $\begin{array}{l}2840-2813 \\
2678-2482\end{array}$ & & \\
\hline Phase 1 & Beta-391200 & wheat grain & $4010 \pm 30$ & $\begin{array}{l}2596-2515 \\
2501-2468\end{array}$ & \begin{tabular}{|l}
$2617-2610$ \\
$2581-2468$
\end{tabular} & & \\
\hline Phase $2 \mathrm{a}$ & OS-93268 & wood charcoal & $3670 \pm 45$ & $\begin{array}{l}2134-2011 \\
2000-1978\end{array}$ & \begin{tabular}{|l}
$2198-2167$ \\
$2149-1928$
\end{tabular} & $\mathrm{n} / \mathrm{a}$ & \\
\hline Phase $2 \mathrm{a}$ & OS-93053* & wood charcoal & $3150 \pm 35$ & $\begin{array}{l}1494-1478 \\
1456-1396\end{array}$ & $\begin{array}{l}1501-1377 \\
1344-1305\end{array}$ & $\begin{array}{l}1408-1378(27.6 \%) \\
1345-1304(40.6 \%)\end{array}$ & 1416-1287 (95.4\%) \\
\hline Phase $2 \mathrm{a}$ & OS-92277* & barley grain & $3090 \pm 40$ & $\begin{array}{l}1413-1370 \\
1360-1298\end{array}$ & $\begin{array}{l}1436-1258 \\
1246-1233\end{array}$ & & \\
\hline Phase $2 \mathrm{a}$ & OS-91990* & barley grain & $3030 \pm 35$ & $\begin{array}{l}1376-1346 \\
1304-1223\end{array}$ & $\begin{array}{l}1405-1192 \\
1143-1132\end{array}$ & & \\
\hline Phase $2 \mathrm{~b}$ & OS-97173 & wood charcoal & $2940 \pm 30$ & $1212-1110$ & \begin{tabular}{|l}
$1256-1250$ \\
$1231-1044$
\end{tabular} & $\begin{array}{c}1194-1142(39.5 \%) \\
1132-1108(22.0 \%)\end{array}$ & $1208-1054(95.4 \%)$ \\
\hline Phase $2 \mathrm{~b}$ & OS-93052 & wood charcoal & $2930 \pm 30$ & $\begin{array}{l}1195-1141 \\
1134-1082 \\
1064-1058\end{array}$ & $1220-1025$ & $1100-1088(6.7 \%)$ & \\
\hline Phase $2 \mathrm{~b}$ & OS-93051 & wood charcoal & $2920 \pm 25$ & $\begin{array}{l}1190-1178 \\
1160-1144 \\
1130-1053\end{array}$ & $1210-1028$ & & \\
\hline Phase 3 & OS-97172 & wood charcoal & $2720 \pm 35$ & $898-830$ & 930-806 & $\mathrm{n} / \mathrm{a}$ & \\
\hline
\end{tabular}

* Samples published in Spengler et al. 2014a: Table 1

** R_combined dates modeled using ${ }^{~}{ }^{14} \mathrm{C}$ date combination" in OxCal version 4.2 (Bronk Ramsey 2009) 


\begin{tabular}{|c|c|c|c|c|c|c|}
\hline Domestic & 12 & 37 & 279 & 191 & 73 & 592 \\
\hline Bos taurus & - & 10 & 61 & 69 & 21 & 161 \\
\hline Equus caballus & - & - & 22 & 18 & 7 & 47 \\
\hline Equus asinus & - & - & 2 & 3 & 1 & 6 \\
\hline Camelus & - & - & - & - & 3 & 3 \\
\hline Caprine & 12 & 23 & 177 & 86 & 32 & 330 \\
\hline Capra hircus & - & 1 & 6 & 6 & 3 & 16 \\
\hline Ovis aries & - & 3 & 11 & 9 & 6 & 29 \\
\hline Wild & 1 & 6 & 16 & 26 & 3 & 52 \\
\hline Bubo bubo & - & - & - & 1 & - & \\
\hline Cervid & - & - & 2 & 7 & 1 & 10 \\
\hline G. subgutturosa & - & 2 & 4 & 4 & 1 & 1 \\
\hline Small rodent & 1 & 1 & 5 & 9 & - & 16 \\
\hline Carnivore & - & - & 2 & 1 & - & \\
\hline Canis $^{\mathrm{a}}$ & - & 2 & 3 & 4 & 1 & 10 \\
\hline Fish $^{\mathrm{b}}$ & - & 1 & - & - & - & \\
\hline Turtle & - & 1 & - & - & - & \\
\hline IDed only to size & 9 & 72 & 318 & 312 & 57 & 768 \\
\hline Large mammal & 1 & 18 & 69 & 80 & 22 & 19 \\
\hline Med. artiodactyl & 7 & 52 & 237 & 224 & 34 & 554 \\
\hline Small mammal & 1 & 2 & 12 & 8 & 1 & 24 \\
\hline Human & 1 & 1 & 2 & 3 & - & 7 \\
\hline Total identified: & 23 & 116 & 615 & 532 & 133 & 1420 \\
\hline Unidentified: & 143 & 354 & 3399 & 2006 & 311 & 621 \\
\hline Net Total: & 166 & 470 & 4014 & 2538 & 444 & 7633 \\
\hline
\end{tabular}

* The bones identified as Canis could not be further identified as wolf or domestic dog; they are listed as wild although they could be either wild or domestic. b. The fish spine was recovered in a flotation sample.

Table 2. Faunal remains from Tasbas, quantified in terms of identified specimens (NISP), according to occupation phases. 


\begin{tabular}{lrrrr}
\multicolumn{1}{c}{ Phase } & & \\
1 & $2 \mathrm{a}$ & $2 \mathrm{~b}$ & 3 & 4
\end{tabular}

\begin{tabular}{|c|c|c|c|c|c|}
\hline \multicolumn{6}{|l|}{ Domestic } \\
\hline Bos taurus & - & 5 & 9 & 7 & 6 \\
\hline Equus caballus & - & - & 5 & 3 & 2 \\
\hline Equus asinus & - & - & 2 & 2 & 1 \\
\hline Camelus & - & - & - & - & 2 \\
\hline Caprine & 2 & 7 & 16 & 6 & 4 \\
\hline Capra hircus & - & 1 & 3 & 2 & 2 \\
\hline Ovis aries & - & 3 & 5 & 3 & 4 \\
\hline \multicolumn{6}{|l|}{ Wild } \\
\hline Bubo bubo & - & - & - & 1 & - \\
\hline Cervid & - & - & 2 & 3 & 1 \\
\hline G. subgutturosa & - & 2 & 2 & 3 & 1 \\
\hline Small rodent & 1 & 1 & 2 & 2 & - \\
\hline Carnivore & - & - & 2 & 1 & - \\
\hline Canis & - & 1 & 3 & 2 & 1 \\
\hline Fish & - & 1 & - & - & - \\
\hline Turtle & - & 1 & - & - & - \\
\hline Human & 1 & 1 & 1 & 3 & - \\
\hline
\end{tabular}

Table 3: Faunal remains from Tasbas, MNI according to occupation phase. 


\begin{tabular}{|l|c|c|c|}
\cline { 2 - 4 } \multicolumn{1}{c|}{} & NISP butchered & Total NISP & \% butchered \\
\hline Phase 1 & 5 & 23 & 22 \\
Phase 2a & 6 & 116 & 5 \\
Phase 2b & 53 & 615 & 9 \\
Phase 3 & 45 & 532 & 8 \\
Phase 4 & 20 & 133 & 15 \\
\hline
\end{tabular}

Table 4: Faunal remains from Tasbas showing butchery by phase, as a percent of NISP 


\begin{tabular}{|c|c|c|c|c|c|c|c|c|c|c|c|c|c|c|c|c|c|c|}
\hline & Archaeological Phase & \multicolumn{5}{|c|}{ Phase 1} & \multicolumn{11}{|c|}{ Phase $2 \mathrm{a}$} & \multirow{4}{*}{$\begin{array}{c}\text { Totals } \\
\text { by } \\
\text { specie } \\
\text { s }\end{array}$} \\
\hline \multicolumn{2}{|c|}{ Macrobotanical Sample No.: } & FS 25 & $\begin{array}{l}\text { FS } \\
26 \\
\end{array}$ & $\begin{array}{l}\mathrm{FS} \\
28 \\
\end{array}$ & $\begin{array}{l}\text { FS } \\
29 \\
\end{array}$ & $\begin{array}{l}\text { FS } \\
30 \\
\end{array}$ & $\begin{array}{l}\mathrm{FS} \\
14 \\
\end{array}$ & $\begin{array}{l}\text { FS } \\
17 \\
\end{array}$ & $\begin{array}{l}\mathrm{FS} \\
18 \\
\end{array}$ & $\begin{array}{l}\text { FS } \\
19 \\
\end{array}$ & $\begin{array}{l}\text { FS } \\
20 \\
\end{array}$ & $\begin{array}{l}\text { FS } \\
21 \\
\end{array}$ & $\begin{array}{l}\text { FS } \\
22 \\
\end{array}$ & $\begin{array}{l}\text { FS } \\
23 \\
\end{array}$ & $\begin{array}{l}\text { FS } \\
24 \\
\end{array}$ & $\begin{array}{l}\text { FS } \\
27 \\
\end{array}$ & $\begin{array}{l}\text { FS } \\
31 \\
\end{array}$ & \\
\hline \multicolumn{2}{|c|}{ Archaeological Feature No.: } & 130 & 132 & 134 & 132 & $\begin{array}{c}13 \\
0\end{array}$ & 106 & 109 & 107 & 110 & 121 & 109 & $\begin{array}{c}109 \\
b\end{array}$ & 123 & 129 & $\begin{array}{c}12 \\
6\end{array}$ & 109 & \\
\hline \multicolumn{2}{|r|}{ Vol. Liters } & 6.2 & 7.2 & 8.0 & 7.0 & 7.0 & 6.6 & 7.5 & 4.0 & 6.8 & 7.0 & 7.0 & 4.7 & 7.0 & 7.4 & 6.4 & 7.0 & \\
\hline \multicolumn{2}{|r|}{ Wood (> 2.oo mm) Ct. } & NC & $\mathrm{NC}$ & 34 & $\mathrm{NC}$ & $\begin{array}{l}\mathrm{N} \\
\mathrm{C}\end{array}$ & $\mathrm{NC}$ & 110 & 151 & $\mathrm{NC}$ & 12 & 64 & $\mathrm{NC}$ & 69 & 240 & $\begin{array}{c}23 \\
2\end{array}$ & 41 & 953 \\
\hline \multicolumn{2}{|r|}{ Wood $(>2.00 \mathrm{~mm})$ Wt. } & 6.83 & $\begin{array}{c}0.2 \\
6\end{array}$ & $\begin{array}{c}0.1 \\
2\end{array}$ & $\begin{array}{c}1.4 \\
5\end{array}$ & 3.1 & $\begin{array}{c}1.5 \\
2\end{array}$ & 0.63 & $\begin{array}{c}1.1 \\
5\end{array}$ & 8.28 & $\begin{array}{c}0.0 \\
6\end{array}$ & $\begin{array}{c}0.2 \\
5\end{array}$ & 4.33 & $\begin{array}{c}0.1 \\
8\end{array}$ & $\begin{array}{c}1.6 \\
9\end{array}$ & 1.8 & $\begin{array}{c}0.2 \\
6\end{array}$ & 31.91 \\
\hline \multirow{7}{*}{ Domesticates } & $\begin{array}{l}\text { Barley (Hordeum vulgare } \\
\text { var. nudum) }\end{array}$ & & & & & & 11 & 157 & & 215 & & 6 & 120 & 31 & 5 & 21 & 11 & 577 \\
\hline & $\begin{array}{l}\text { Wheat (Triticum } \\
\text { aestivum/ turigidum) }\end{array}$ & & 1 & & & 4 & & 1 & & 2 & & & & & & & & 8 \\
\hline & $\begin{array}{l}\text { Millet (Panicum } \\
\text { miliaceum) }\end{array}$ & & & & & & 20 & 11 & 2 & 4 & & & & 1 & 1 & 2 & 12 & 53 \\
\hline & $\begin{array}{l}\text { Millet (Cf. Setaria } \\
\text { italica) }\end{array}$ & & & & & & 5 & & & 5 & & & & & & 1 & & 11 \\
\hline & $\begin{array}{l}\text { Green Peas (Pisum } \\
\text { sativum) }\end{array}$ & & & & & & & 5 & & 50 & & & 20 & & 3 & 1 & 1 & 80 \\
\hline & Cerealia & 5 & 2 & & & 4 & 13 & 266 & & 238 & & 38 & 87 & 23 & 22 & 22 & & 720 \\
\hline & Rachis & & & & & & & 64 & & 1 & & & 125 & 3 & & & 1 & 194 \\
\hline \multirow{2}{*}{$\begin{array}{l}\text { Domesticates } \\
\text { /Wild }\end{array}$} & $\begin{array}{l}\text { Millet - immature or } \\
\text { wild }\end{array}$ & & & & & & 1 & & & & & & & & & & & 1 \\
\hline & $\begin{array}{l}\text { Barley - immature or } \\
\text { wild }\end{array}$ & & & & & & 1 & & & 16 & & & 6 & 3 & 1 & & & 27 \\
\hline \multirow{5}{*}{ Poaceae } & Poaceae & & & & & & 6 & 7 & 1 & & 3 & & 9 & & 9 & 6 & & 41 \\
\hline & Panicoid-Type & & & & & & 6 & 3 & & 6 & & & 2 & & 2 & 3 & 1 & 23 \\
\hline & Pooid-Type & & & & & & 6 & 16 & & 9 & & & 12 & & & 1 & & 44 \\
\hline & Setaria (cf. viridis) & & & & & & 9 & 9 & 1 & 13 & 1 & 1 & 49 & & 2 & & 3 & 88 \\
\hline & Stipa-Type & & & & & & & 6 & & 173 & & & 4 & & 3 & 2 & & 188 \\
\hline \multirow{2}{*}{ Amaranthaceae } & Chenopodium spp. & & 1 & & & & 23 & 71 & 3 & 214 & & & 34 & 1 & 32 & 31 & & 410 \\
\hline & Cheno-ams & & 1 & & & & 2 & 42 & 3 & 24 & 3 & & 5 & & 28 & 22 & & 130 \\
\hline
\end{tabular}




\begin{tabular}{|c|c|c|c|c|c|c|c|c|c|c|c|c|c|c|c|c|c|c|}
\hline Rubiaceae & Galium sp. & 1 & & & & & 1 & 3 & & 14 & 7 & 1 & & 3 & 13 & 3 & & 46 \\
\hline \multirow{2}{*}{ Solanaceae } & Solanaceae & & & & & & 1 & 1 & & 1 & & & & & & & & 3 \\
\hline & Hyoscyamus niger & & & & & & & & & & & & & & 4 & & & 4 \\
\hline \multirow{2}{*}{ Polygonaceae } & Polygonaceae & & & & & & 2 & & & & & & & & & & 1 & 3 \\
\hline & Polygonum spp. & & & & & & 5 & 6 & & 16 & & & 5 & 4 & 4 & 1 & & 41 \\
\hline \multirow{2}{*}{$\begin{array}{l}\text { Caryophyllacea } \\
\text { e }\end{array}$} & Caryophyllaceae & & & & & & & & & & & & 1 & & & & & 1 \\
\hline & Vaccaria/Saponaria & & & & & & 6 & $\begin{array}{c}110 \\
8 \\
\end{array}$ & & $\begin{array}{c}114 \\
1 \\
\end{array}$ & & 19 & 49 & 2 & 6 & 4 & & 2335 \\
\hline Boraginaceae & Lithospermum arvense & & & & & & & 1 & & & & & & & & 1 & & 2 \\
\hline Rosaceae & Fragaria/Potentilla & & & & & & & 2 & & 3 & & & 1 & & 1 & 1 & & 8 \\
\hline \multirow{2}{*}{ Fabaceae } & Fabaceae & & & & & & 1 & 1 & & & & & & 2 & 1 & & & 5 \\
\hline & Trigonella-Type & & 2 & 2 & & & 6 & 37 & 43 & 60 & & & 23 & & 18 & 13 & & 204 \\
\hline Cyperaceae & Cyperaceae & 1 & & & & & & 14 & & 3 & & & 25 & 2 & 1 & 2 & & 48 \\
\hline Lamiaceae & Ajuga & & & & & & & & & 4 & & & & & & 1 & & 5 \\
\hline Asteraceae & Asteraceae & & & & & & 3 & & & 1 & & & & & & & & 4 \\
\hline Unidentified & Unidentified Seed & 1 & & & & & 2 & 8 & & 20 & & & 1 & & 3 & 1 & & 36 \\
\hline Unidentifiable & $\begin{array}{l}\text { Unidentifiable Seed } \\
\text { Fragments }\end{array}$ & & & 3 & 1 & 3 & & 221 & 52 & 681 & 7 & 2 & 521 & 14 & 190 & 50 & & 1745 \\
\hline \multicolumn{2}{|c|}{$\begin{array}{c}\text { Totals w/out Unidentifiable Fragments } \\
\text { or Rachises }\end{array}$} & 8 & 7 & 2 & 0 & 8 & 130 & $\begin{array}{c}178 \\
5\end{array}$ & 53 & $\begin{array}{c}223 \\
2 \\
\end{array}$ & 14 & 65 & 447 & 72 & 159 & $\begin{array}{c}13 \\
9\end{array}$ & 29 & \\
\hline
\end{tabular}

Table 5: Tasbas macrobotanical assemblage for wild and domesticated plants from Phases 1 and 2a. Table includes raw counts for wood fragments and seeds, archaeological phase, macrobotanical sample number, archaeological feature number, and volume of soil liters collected. 


\begin{tabular}{|c|c|c|c|c|c|c|c|c|c|c|c|c|c|c|c|c|c|c|c|c|c|c|c|c|c|c|c|c|c|c|c|c|c|c|c|}
\hline $\begin{array}{l}\text { Archaeological } \\
\text { Phase }\end{array}$ & 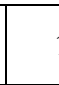 & 1 & \multicolumn{10}{|c|}{$2 a$} & \multicolumn{15}{|c|}{$2 \mathrm{~b}$} & \multicolumn{6}{|c|}{3} & \multicolumn{2}{|c|}{$\begin{array}{c}\text { Off- } \\
\text { site }\end{array}$} \\
\hline $\begin{array}{l}\text { Phytolith Sample } \\
\text { No.: }\end{array}$ & $\begin{array}{l}\stackrel{a}{\vec{N}} \\
\stackrel{\vec{\nu}}{\vec{D}} \\
\vec{\sim}\end{array}$ & 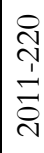 & 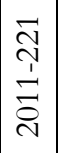 & 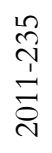 & 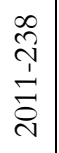 & 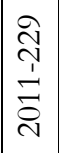 & 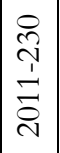 & 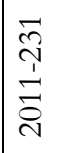 & 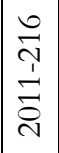 & $\mid \begin{array}{c}\vec{\sim} \\
\stackrel{\vec{v}}{\vec{\Delta}} \\
\overrightarrow{\vec{\sigma}}\end{array}$ & $\left|\begin{array}{c}\infty \\
\vec{\sim} \\
\overrightarrow{\vec{\sim}} \\
\vec{\sim} \\
\mid\end{array}\right|$ & 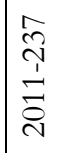 & 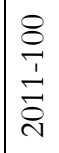 & 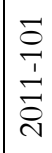 & 总 & ô & 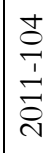 & 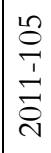 & 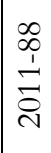 & $\mid \begin{array}{c}\infty \\
\dot{1} \\
\overrightarrow{\vec{D}} \\
\dot{\vec{n}}\end{array}$ & 方 & 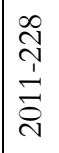 & $\begin{array}{l}\stackrel{n}{a} \\
\stackrel{i}{\vec{D}} \\
\stackrel{v}{v}\end{array}$ & 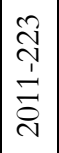 & 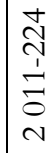 & 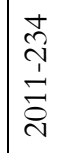 & 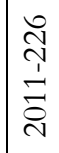 & a & $\frac{\dot{t}}{\stackrel{1}{\vec{s}}}$ & 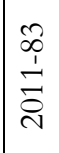 & $\vec{a}$ & 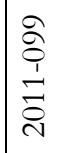 & 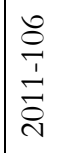 & 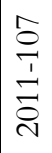 & 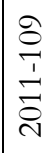 \\
\hline $\begin{array}{l}\text { Archaeological } \\
\text { Feature No.: }\end{array}$ & $\stackrel{m}{\sim}$ & $\stackrel{\stackrel{n}{2}}{\sim}$ & $\stackrel{2}{\circ}$ & $\stackrel{8}{\circ}$ & $\stackrel{5}{\circ}$ & $\stackrel{8}{\circ}$ & $\stackrel{8}{\circ}$ & $\stackrel{\rho}{0}$ & $\exists$ & $\Xi$ & 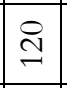 & $\vec{I}$ & 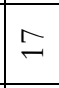 & 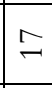 & 三 & 二 & 군 & 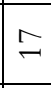 & $\cong$ & 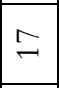 & $\cong$ & $\approx$ & $\approx$ & $\ddot{\vec{\sigma}}$ & $\stackrel{5}{-}$ & 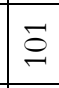 & 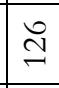 & $\sigma$ & $a$ & $a$ & $a$ & $a$ & ป & $\frac{\pi}{l}$ & $\stackrel{\sigma}{a}$ \\
\hline $\begin{array}{l}\text { Wheat (Triticum } \\
\text { aestivum/ turigidum) }\end{array}$ & & & & & & & & & & & ? & & ૫ & & & & & & & & ? & & & & & & Q & ૫ & & & & & & & \\
\hline $\begin{array}{l}\text { Barley (Hordeum } \\
\text { vulgare) }\end{array}$ & & & & Q & 0 & 0 & ? & ? & & & & ? & & & & & & & & & & & & & & ? & & & & & & & & & \\
\hline $\begin{array}{l}\text { Millet (Setaria } \\
\text { italica or Panicum } \\
\text { miliaceum) }\end{array}$ & & & 0 & 0 & & & & & & & & ૫ & प & $\square$ & — & ૫ & ? & & 0 & 0 & $?$ & ૫ & 0 & Q & ૫ & ૫ & ૫ & ૧ & ૧ & Q & $?$ & & & & \\
\hline Setaria italica & & & & & & & & & & & & & & & & & $?$ & & $\square$ & & & & & & & & & & & & & & & & \\
\hline $\begin{array}{r}\text { Panicum } \\
\text { miliaceum }\end{array}$ & & & 0 & Q & & & & & & & & & & & & & & ? & ૧ & & ? & प & & Q & प & प & Q & & & & $?$ & & & & \\
\hline $\begin{array}{l}\text { Sedge } \\
\text { (Cyperaceae) }\end{array}$ & & — & 0 & 0 & & 0 & & & ૧ & प & & & & & — & ૫ & & ૫ & ૫ & 0 & & & 0 & 0 & ૫ & ૫ & ૫ & ૧ & ૫ & 0 & Q & & ૫ & & \\
\hline $\begin{array}{l}\text { Reed (Phragmites } \\
\text { australis) }\end{array}$ & & प & \begin{tabular}{|l|}
0 \\
\end{tabular} & Q & Q & 0 & 0 & & 0 & ૧ & ૫ & & & & & — & & & 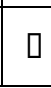 & 0 & & & & Q & ૫ & ૫ & ૫ & & Q & & Q & 0 & 0 & & \\
\hline
\end{tabular}

Table 6: Tasbas phytolith assemblage showing presence/absence of wild and domesticated plants from Bronze Age Phases 1-3.

Table includes archaeological phase, phytolith sample number, and archaeological feature number. Presence (D) and tentative

(?) identifications are marked for each plant. 


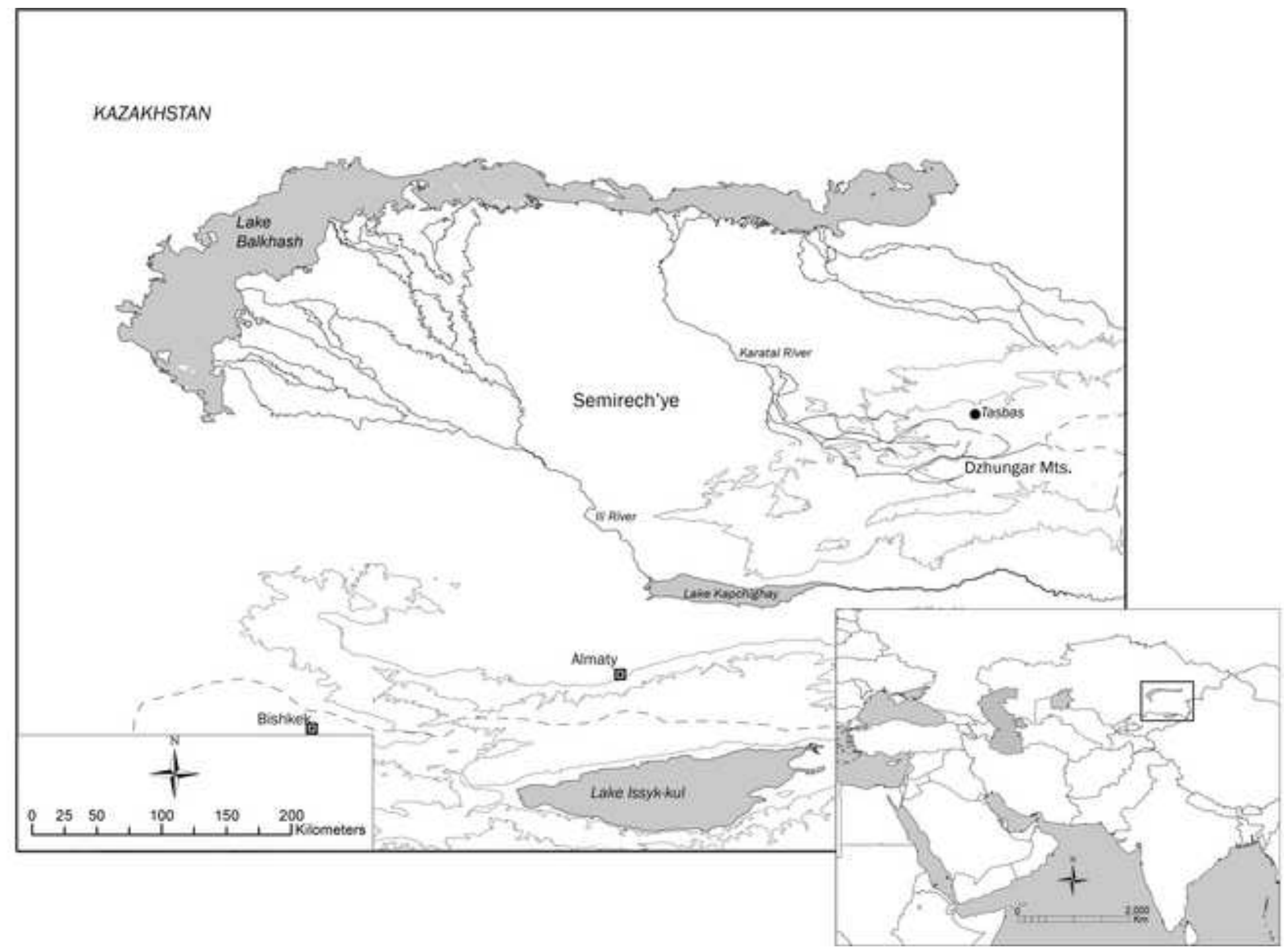




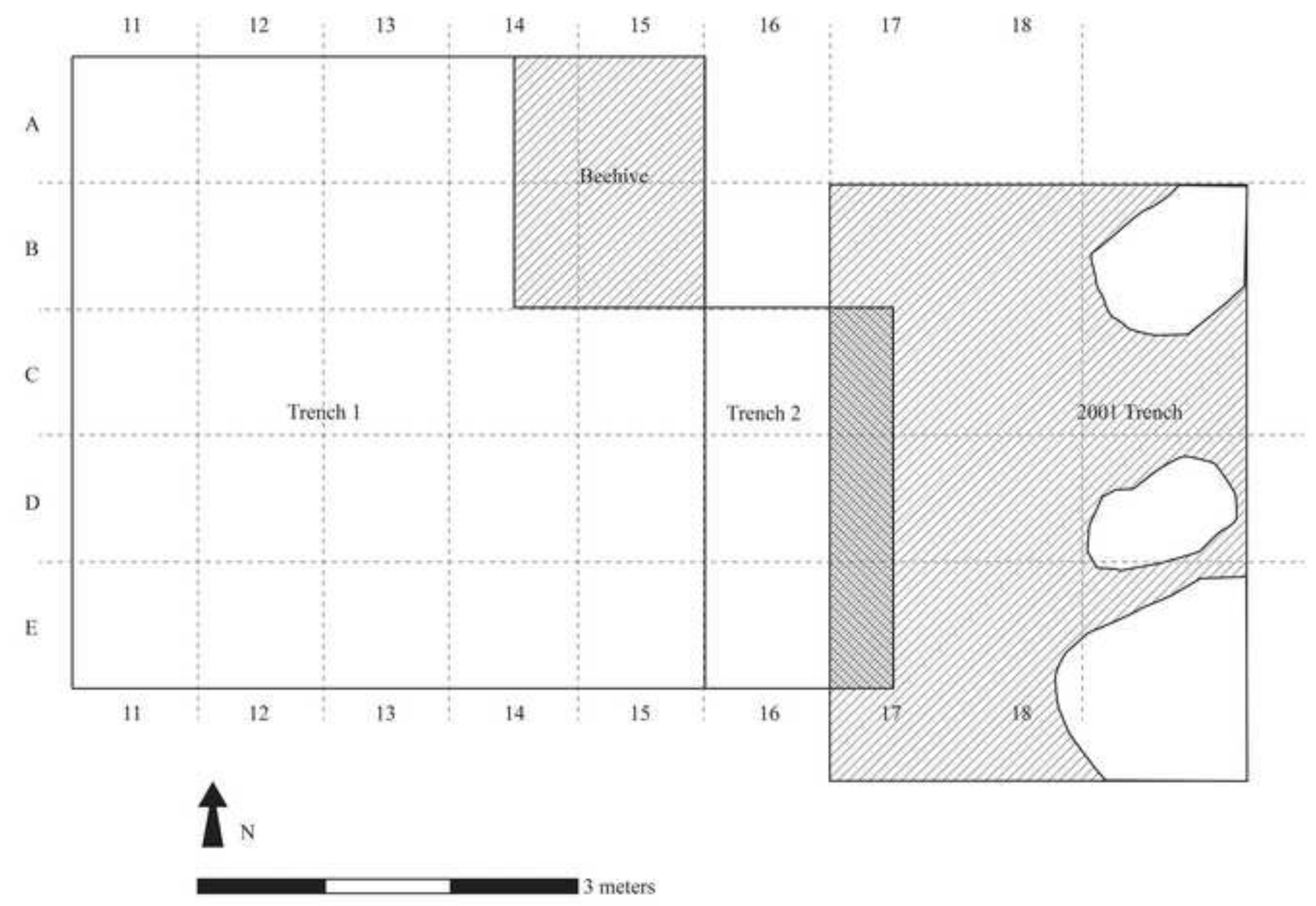

sas site plan 
Trench 2, west section

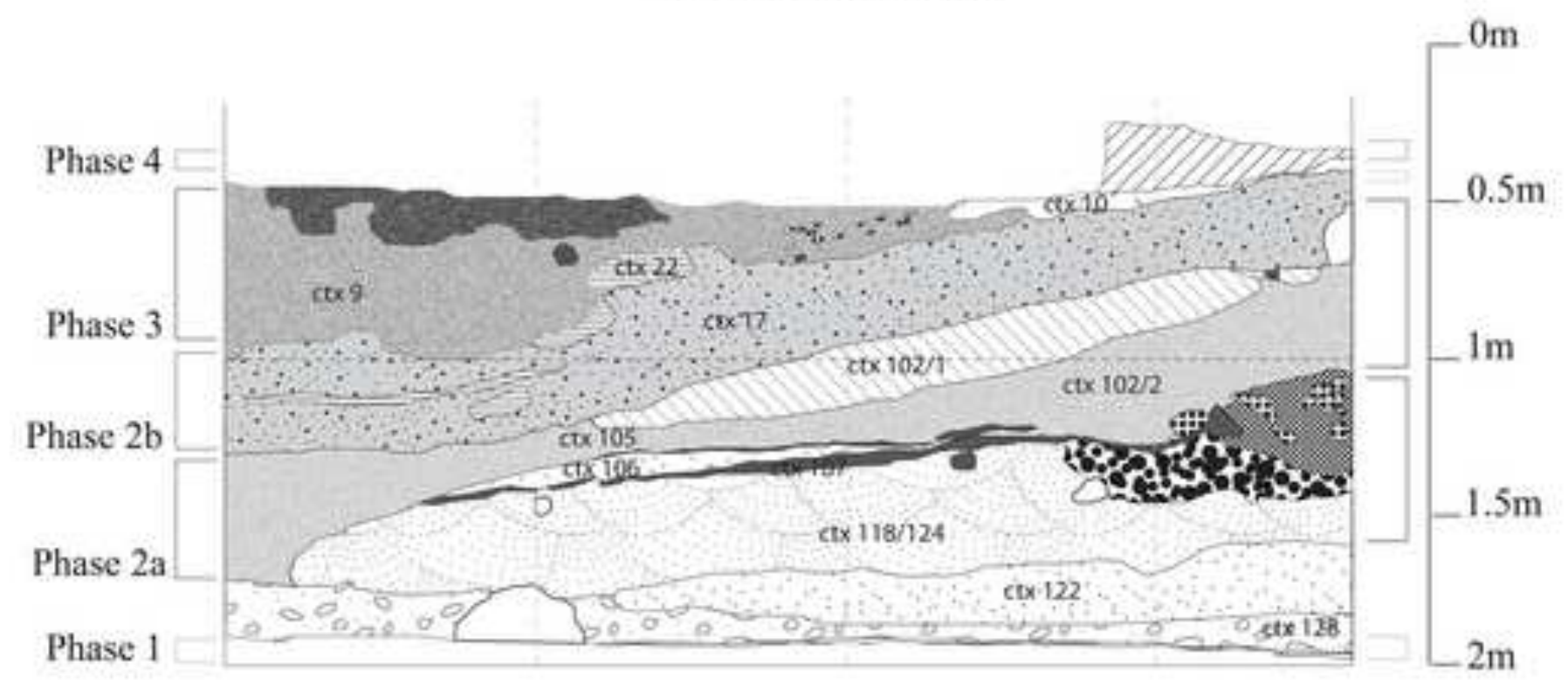

Trench 1 , south section

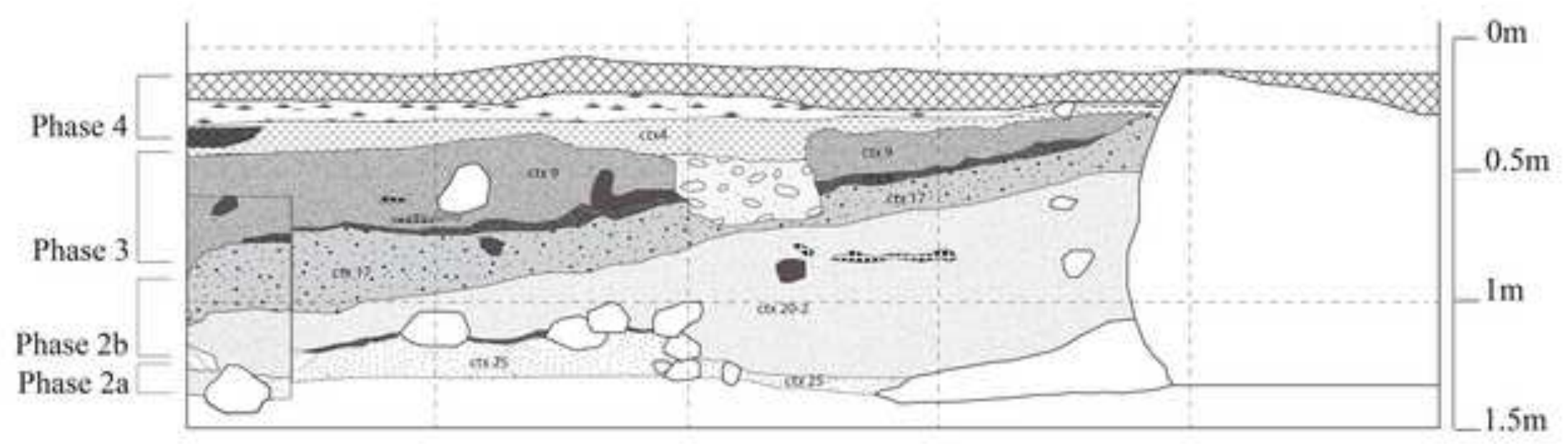



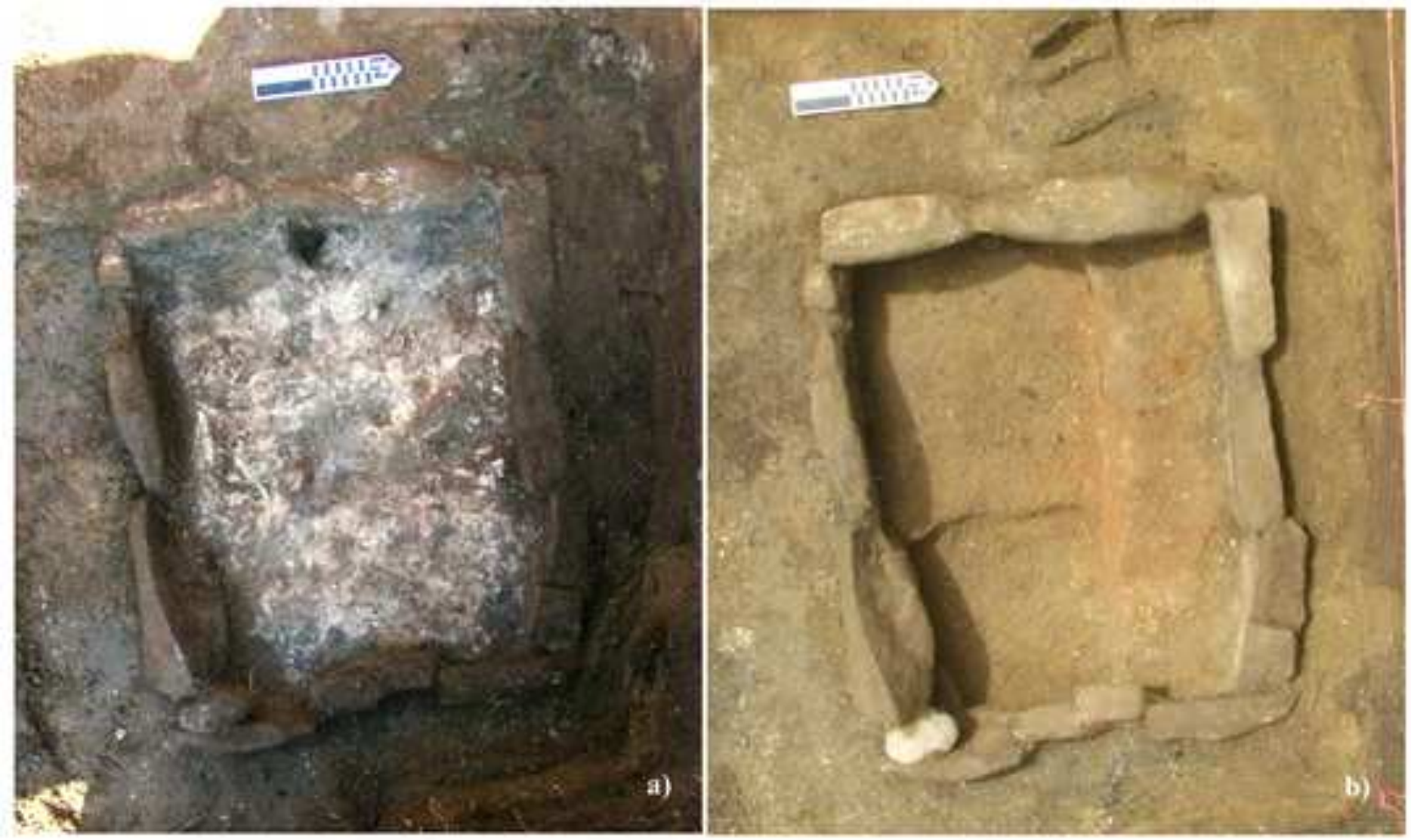

$$
\text { 8. }
$$$$
\text { 5. }
$$

c)
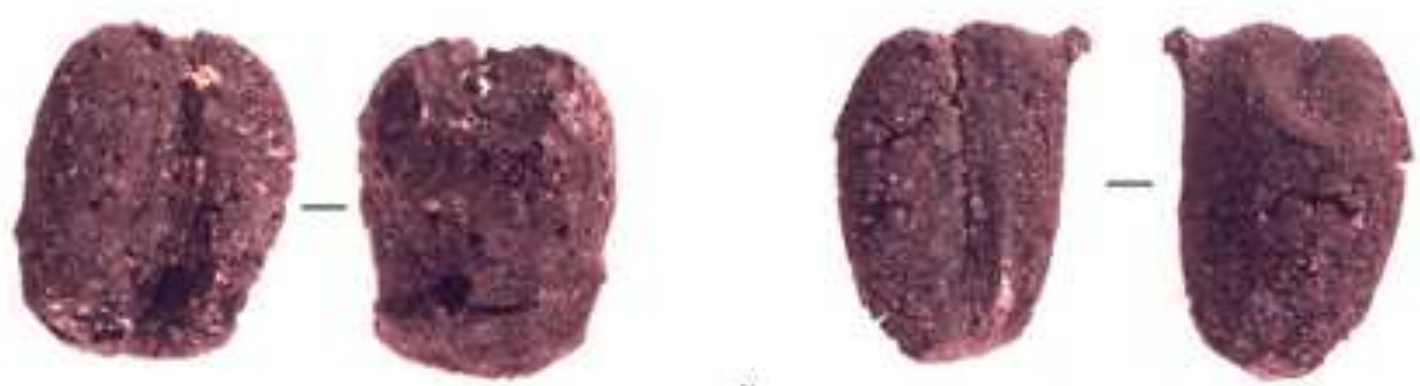
a)
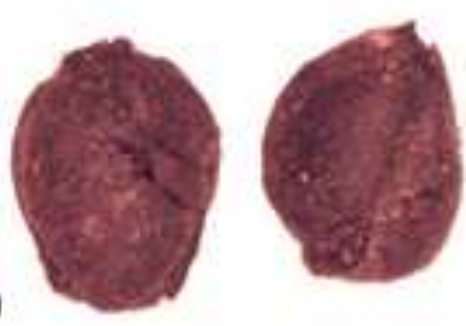

d)

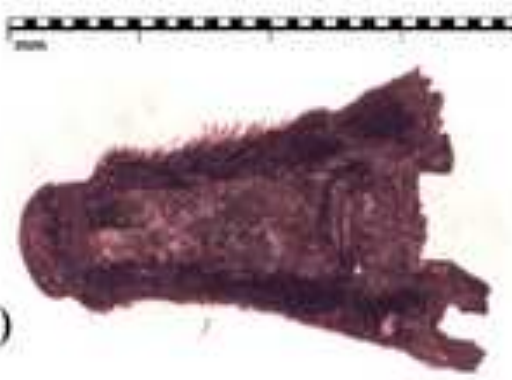

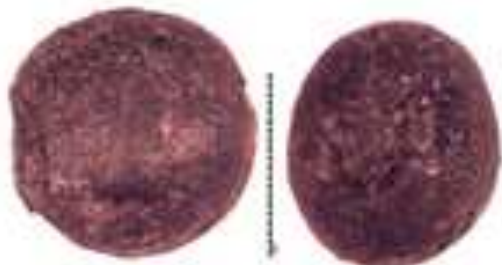

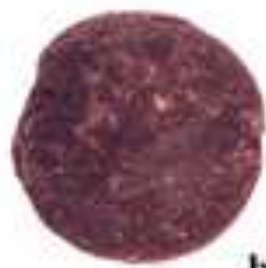

b)
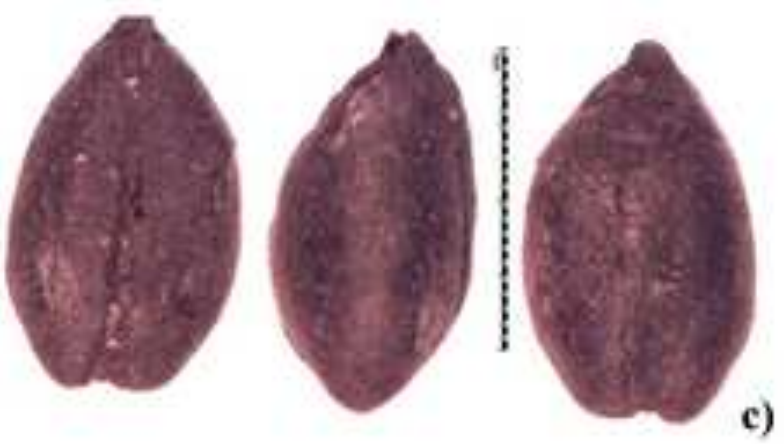

c)
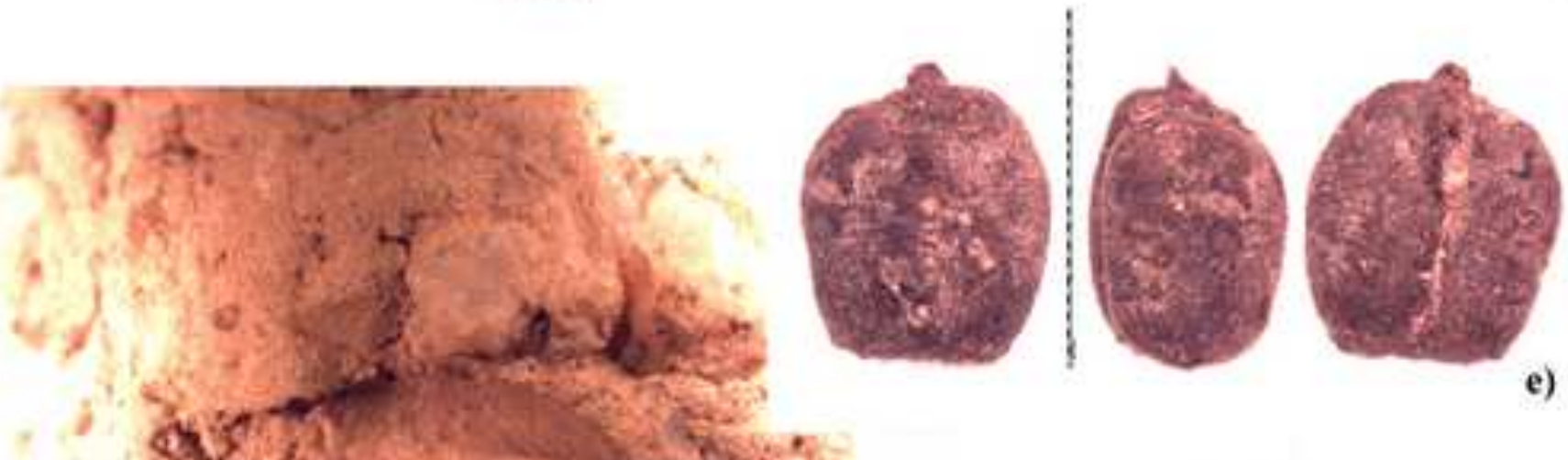

e)

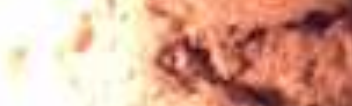

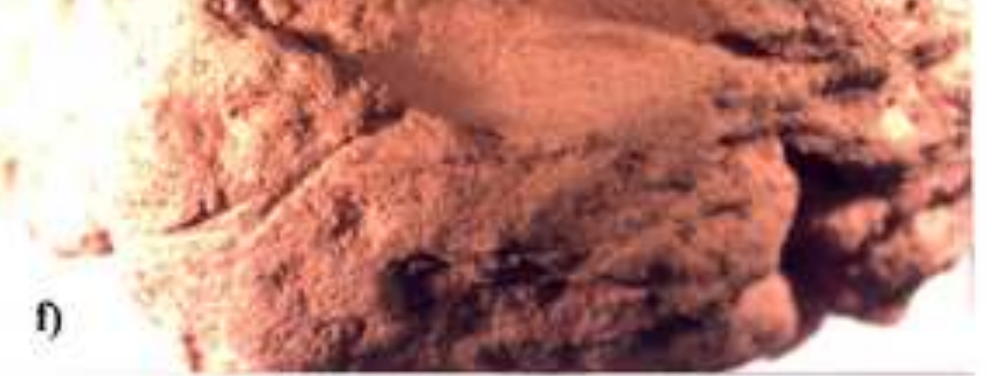

요

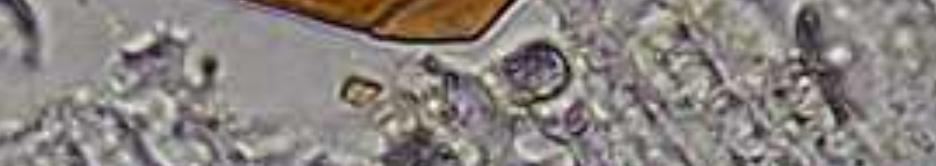

s. Nut

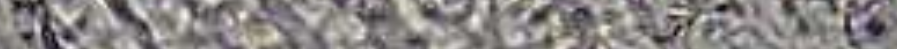

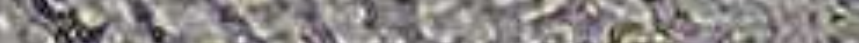

3. S)

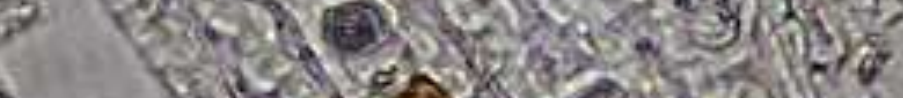

7.

(3)

h)

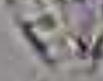
-
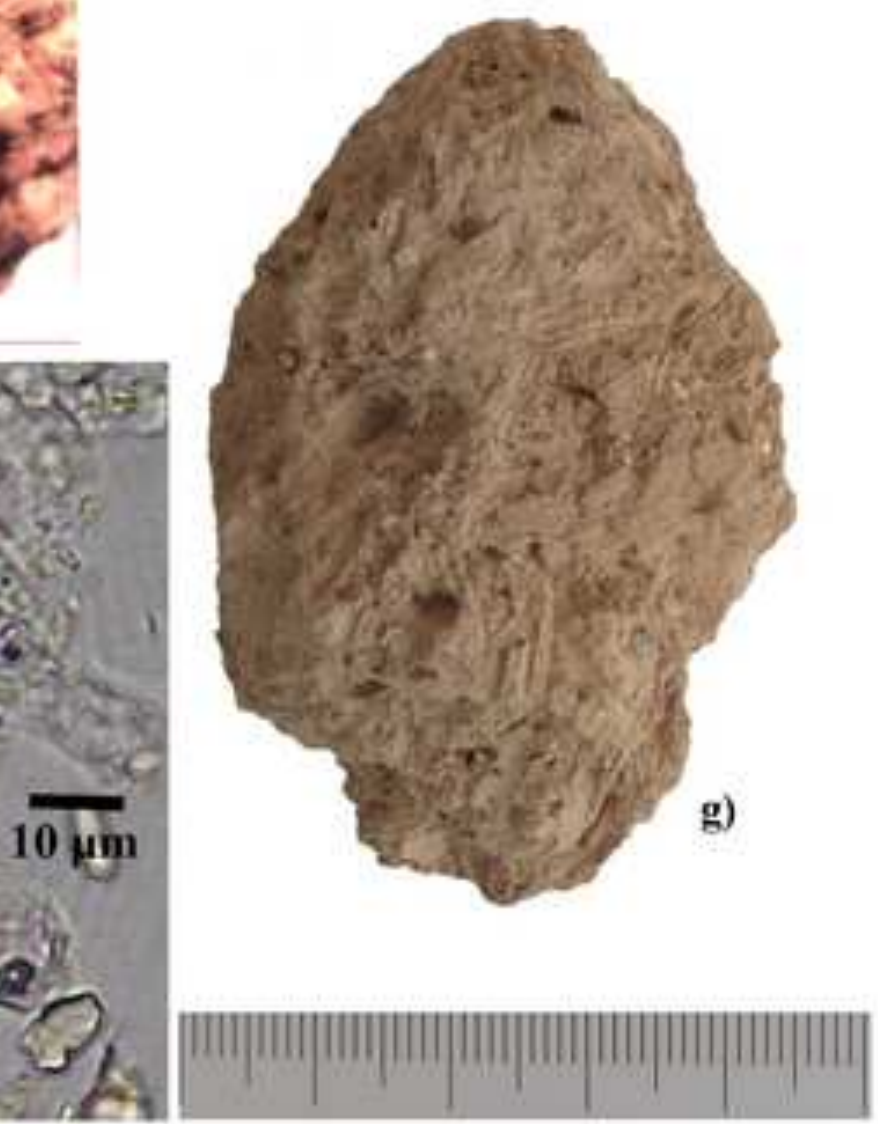


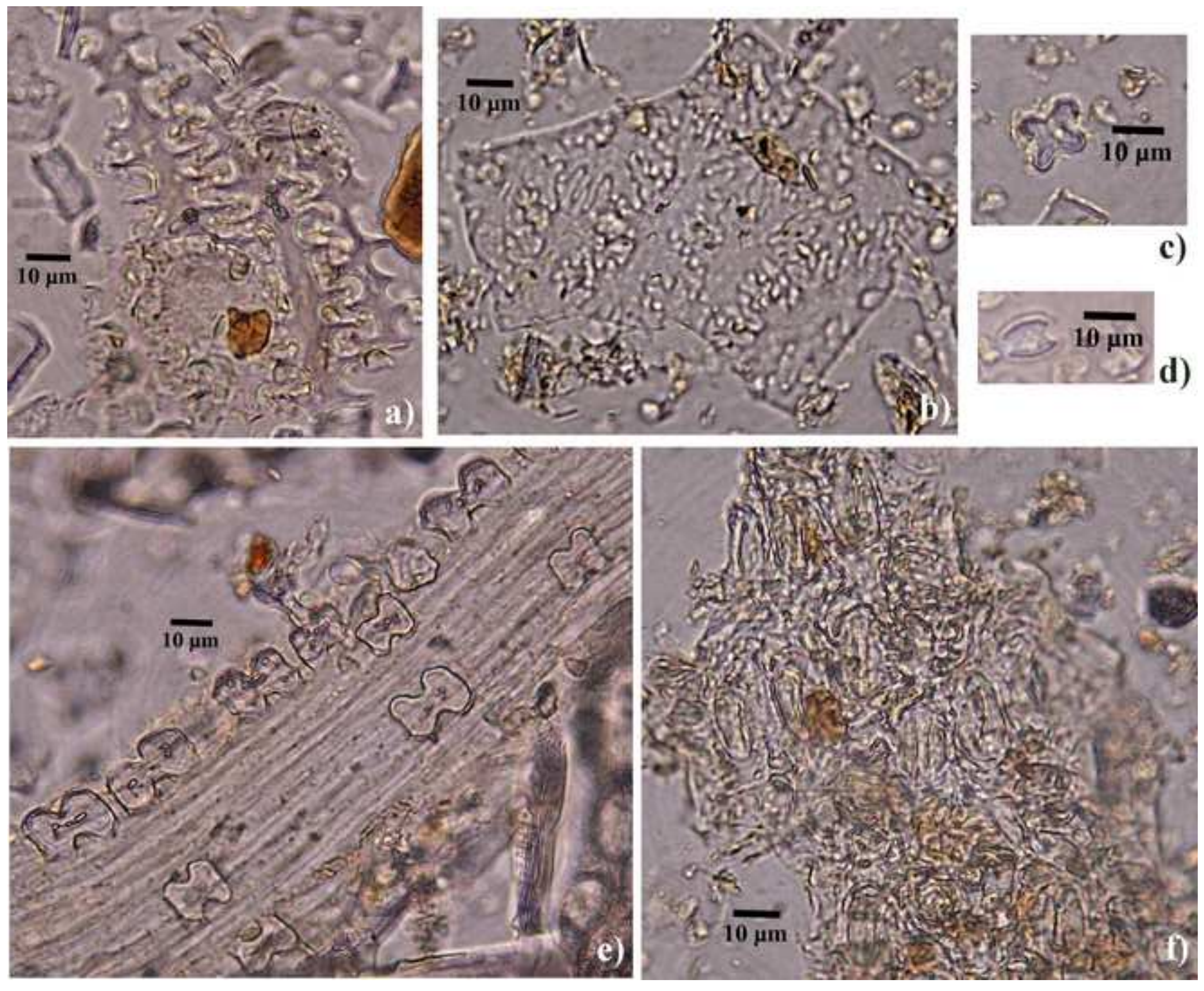




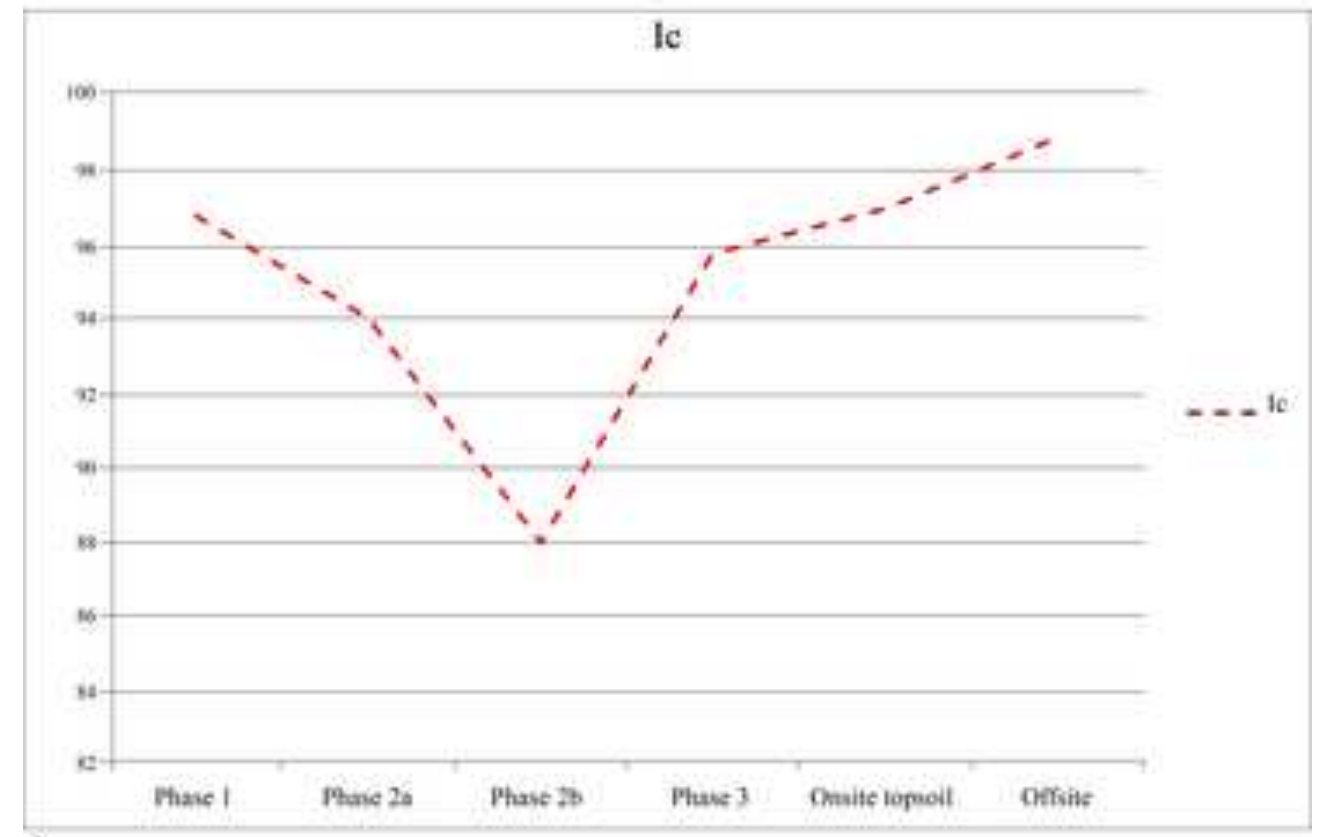

a).

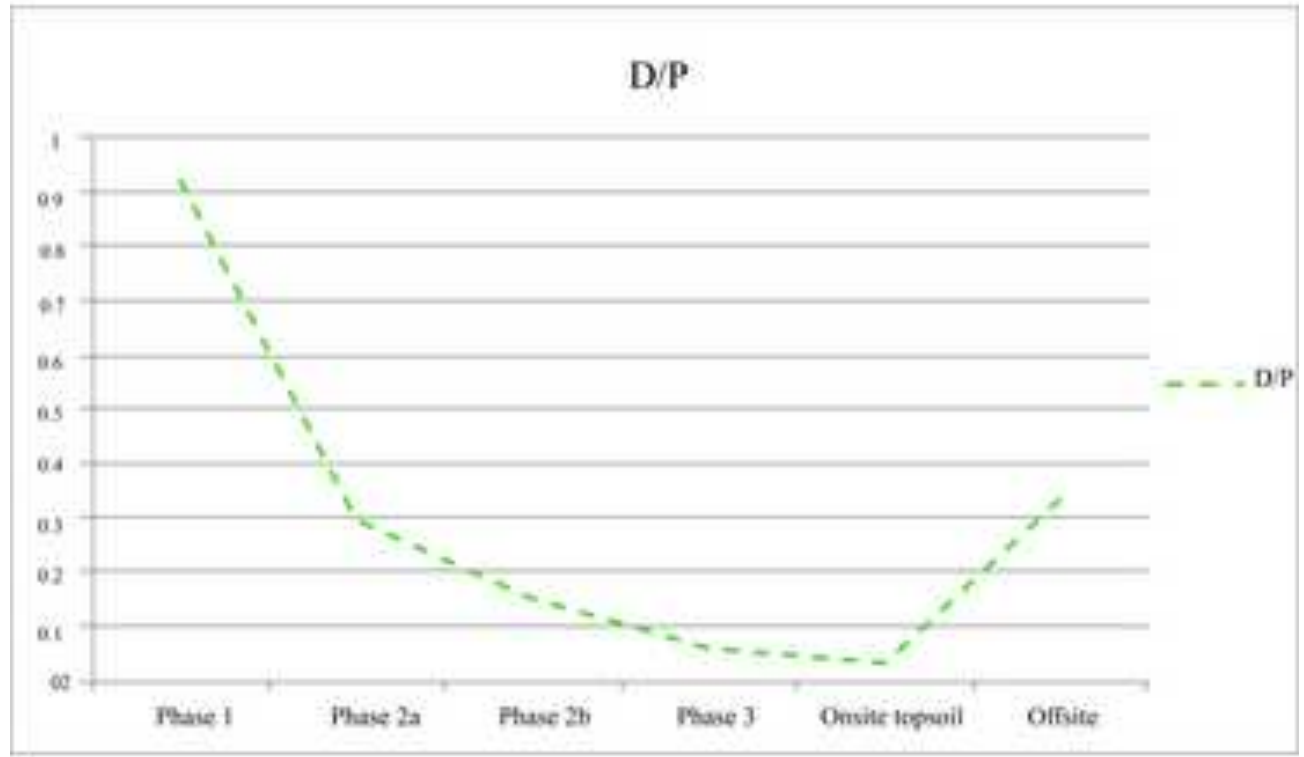

b)

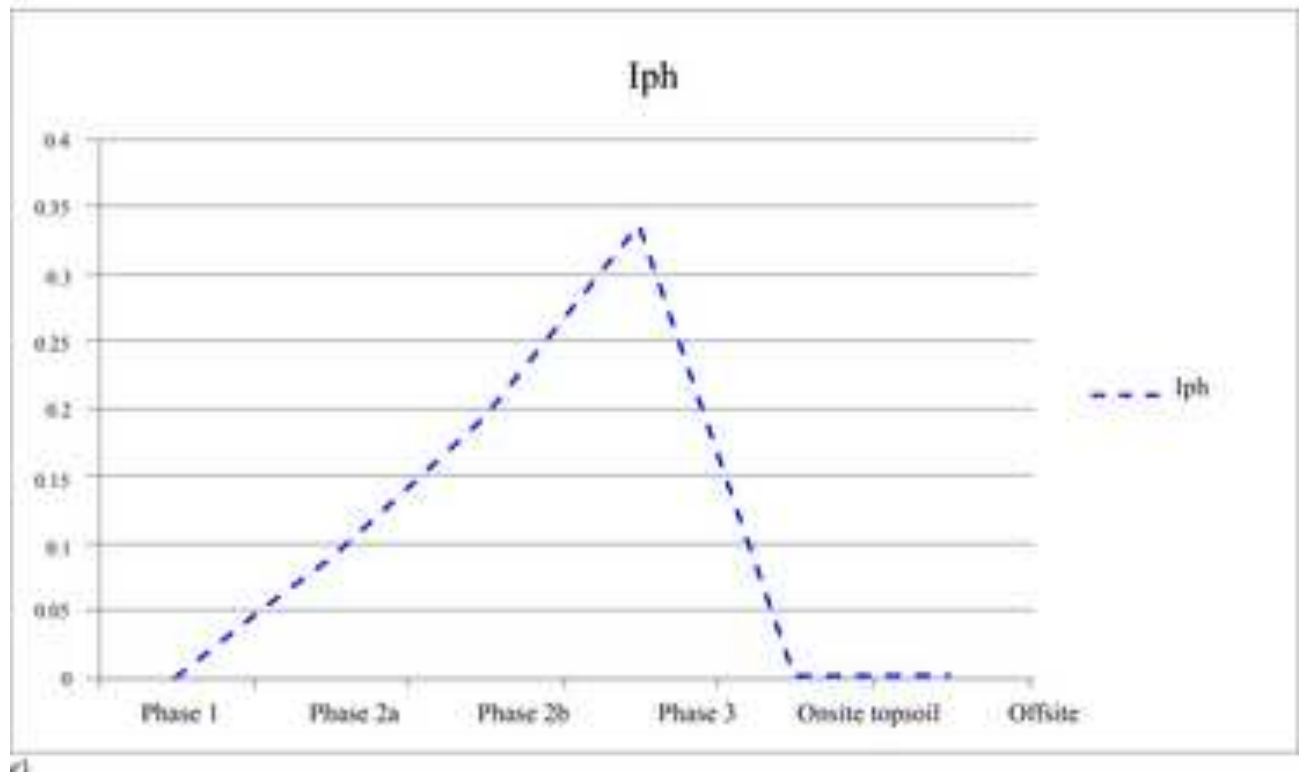



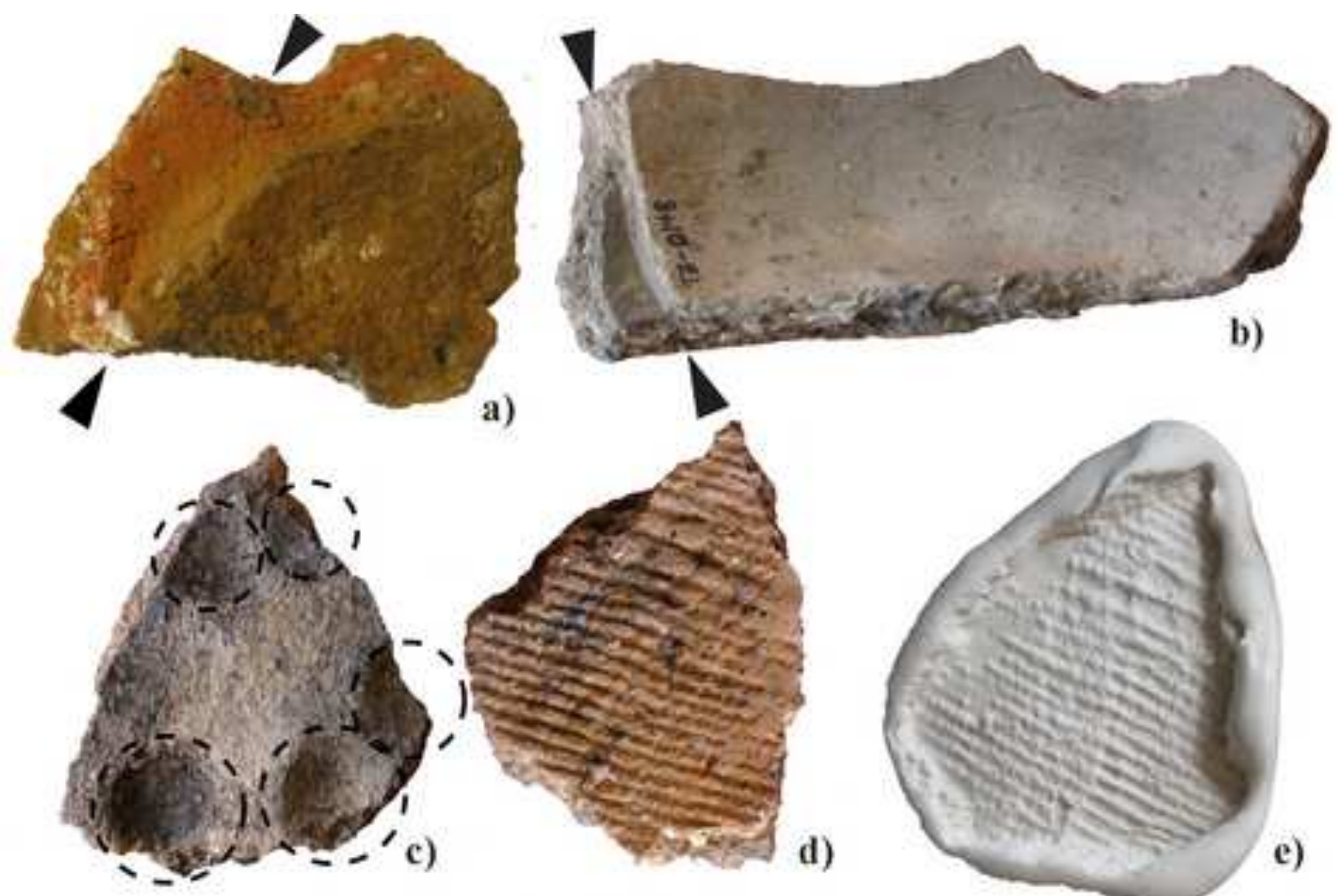

a)

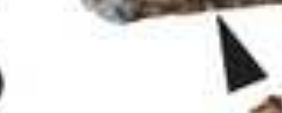

b)

e)

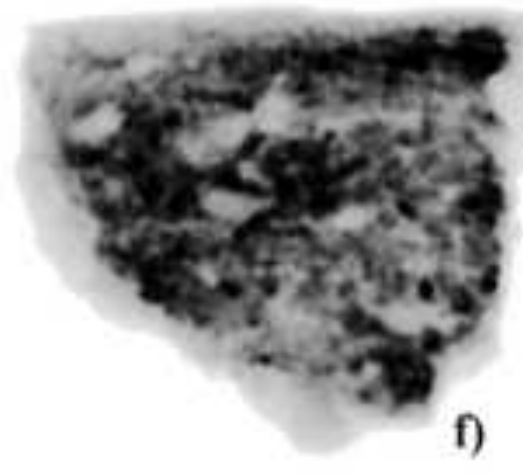

d)
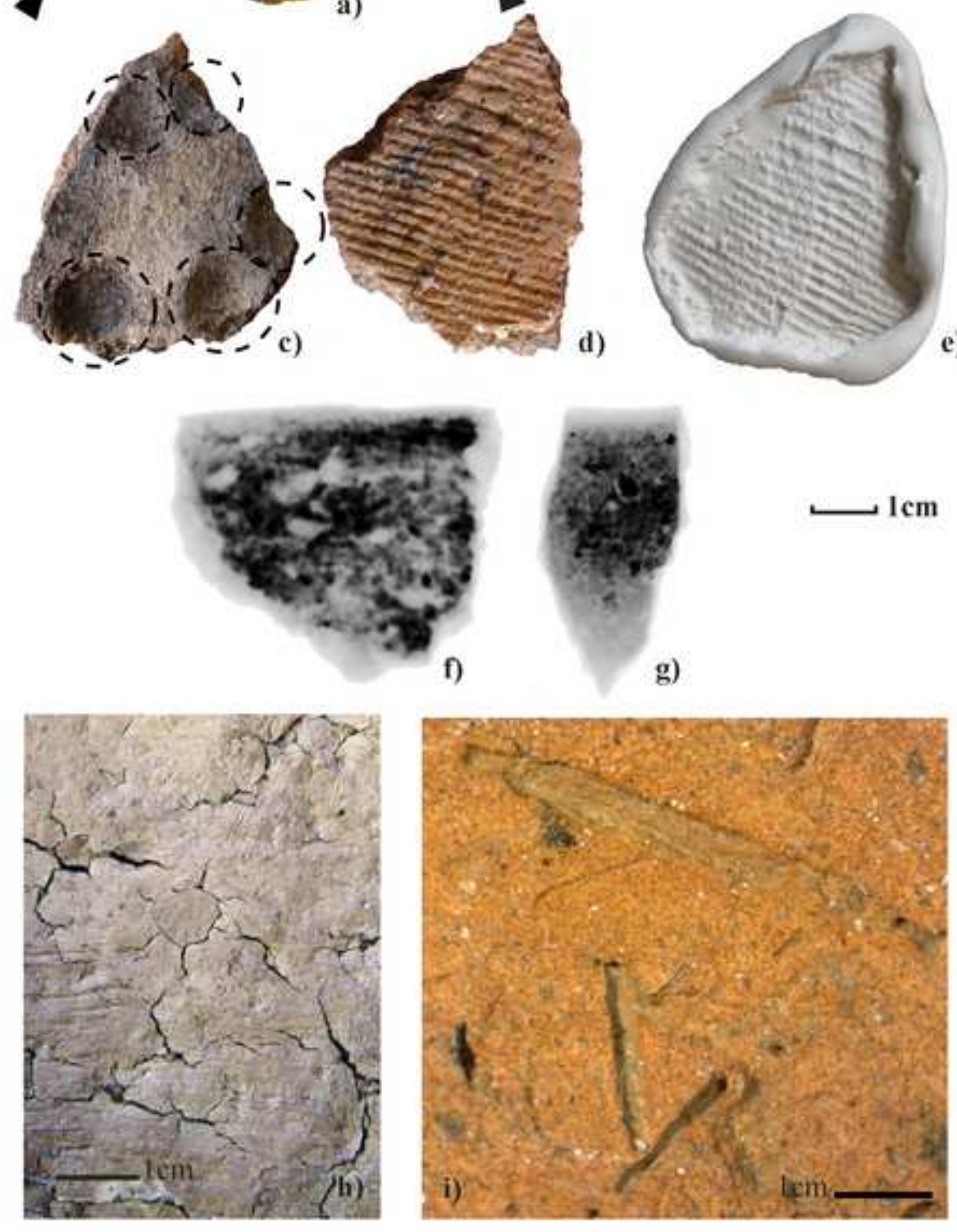

)

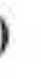


Figure10

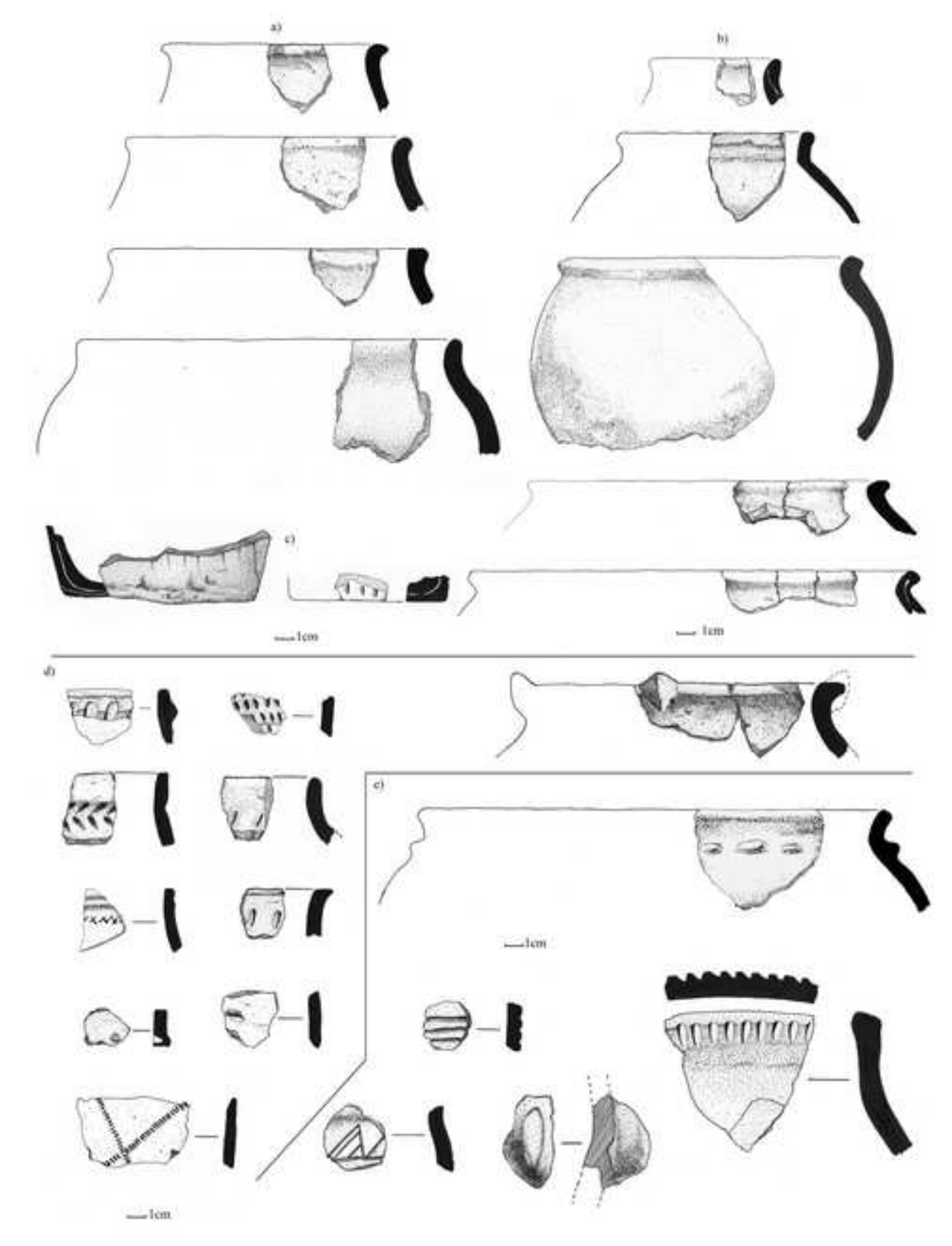

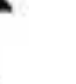

Figure10
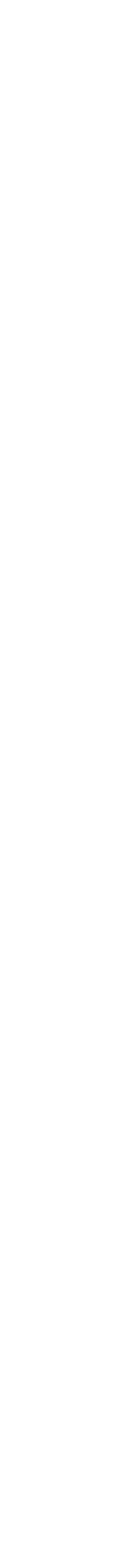

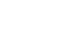

$$
\text { - }
$$

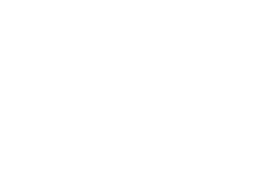




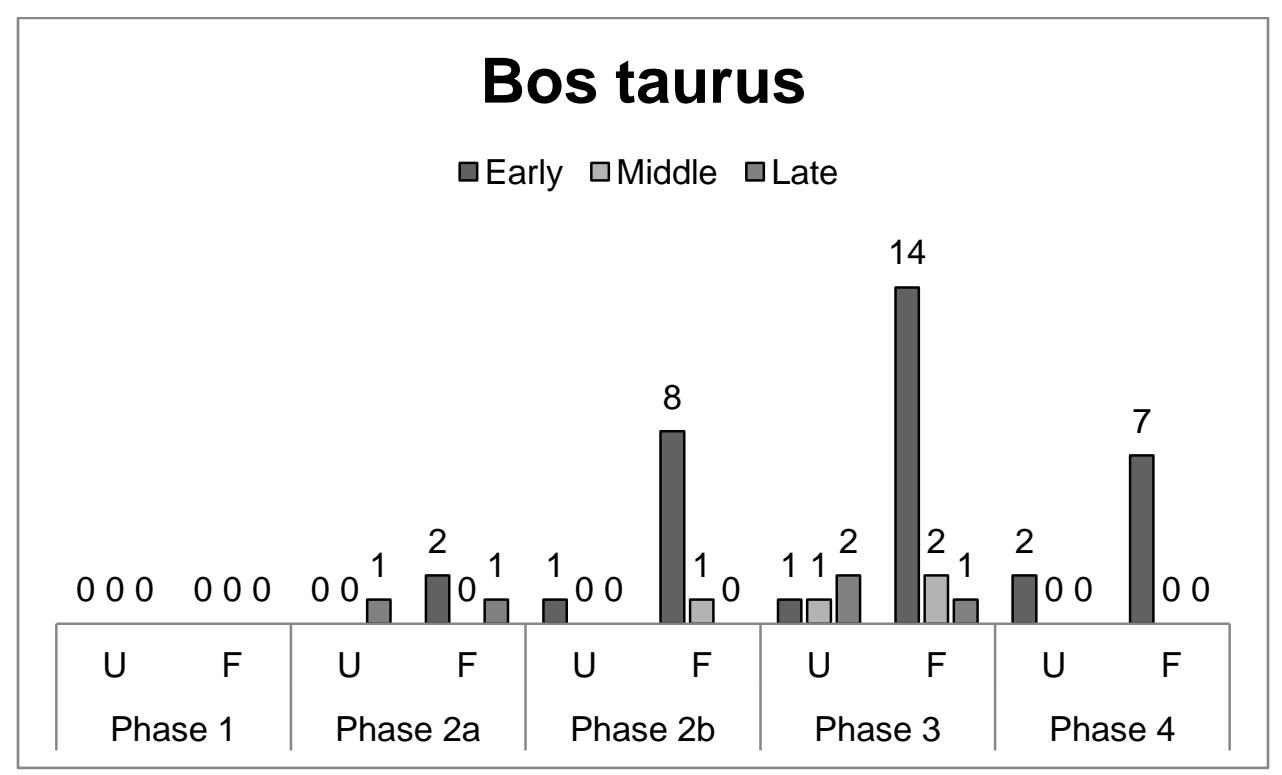

a)

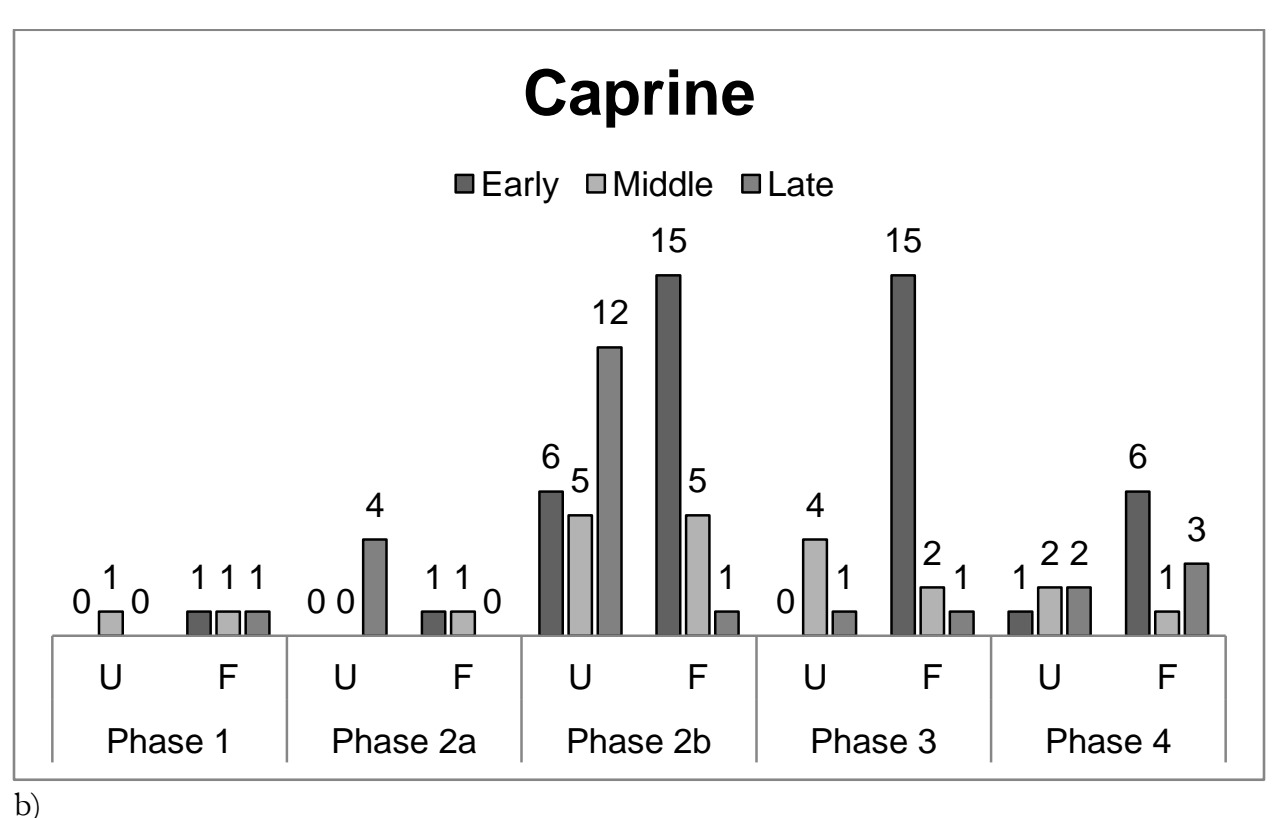

b)

\title{
Bos taurus
}

\author{
$\square$ Early $\square$ Middle $\square$ Late
}

